\title{
Tefsirin Erken Döneminde Tevil: Mücâhid b. Cebr'in Aklî Yorumları*
}

\author{
Mesut Kaya ${ }^{* *}$
}

\begin{abstract}
Tâbiînin ileri gelenlerinden olan ve rical âlimlerinin kāri, fakih ve sika bir âlim oldugunda ittifak ettikleri Mücâhid b. Cebr, tefsirde görüşlerine çokça müracaat edilen bir otoritedir. Şâfiî, Ahmed b. Hanbel, Buhârî ve Taberî gibi âlimlerin Mücâhid’in tefsirdeki görüşlerine itimat etmiş olmaları, bu durumun en önemli göstergesidir. Mücâhid bu özelliklerinin yanında, Kur'ân-ı Kerim'de bazı kıssaların anlatıldığı yerleri bizzat görmek için seyahat etmek, belirli konularda Ehl-i kitaba bilgi sormak ve tefsirde reye önem vermek gibi yönleriyle de dikkat çekmiştir. Rey tefsiri kapsamında değerlendirilebilecek olan ve kimi âyetlerin tefsirinde kullandığı "mesel/temsil" ifadesi, Mücâhid'in bazı âyetleri tevil etme eğiliminde olduğunu göstermektedir. Onun bu tür görüşleri, klasik dönemde ihtiyatla yaklaşılması gereken yorumlar olarak görülüp Taberî gibi müfessirlerce tenkit edilirken, çağdaş dönemde aklî tefsirin kapısını aralayan ve bu yönüyle Mưtezile gibi fırkaların tefsir anlayışına öncülük ettiği ileri sürülen bir müfessir olarak telakki edilmesine yol açmıştır. Bu makale Mücâhid'in tevillerinin mahiyetini ve ona nispet edilen farklı tefsir vecihlerinden bir kısmını konu edinecek, onun aklî tefsirin öncüsü olup olmadığı meselesini tartışacaktır.
\end{abstract}

Anahtar kelimeler: Tefsir, Mücâhid b. Cebr, tevil, rey, aklî tefsir.

\section{Giriș}

Mücâhid b. Cebr (ö. 103/721), tâbiîn neslinden ve tefsir ilminin öncü simalarından biridir. Hz. Ömer (ö. 23/644) döneminde, 21 (642) yilında Mekke'de doğmuş olan Mücâhid'in künyesi Ebü'l-Haccâc olup Kays b. Sâib el-Mahzûmînin (ö. 70/689-690) mevlasıdır. İbn Sa'd’ın (ö. 230/845) rivayetine göre Mücâhid'in bizzat kendisi, Sâib’e hizmet ettiğini anlatmıştır.

* Makaleye katkılarından dolayı Prof.Dr. Harun Öğmüş, Dr. Yusuf Daşdemir ve Arş. Gör. Hatice Tekin’e teșekkür ederim.

** Doç.Dr., Necmettin Erbakan Üniversitesi Ahmet Keleşoğlu İlahiyat Fakültesi ORCID oooo-0003-0884-8340 mesudkaya@hotmail.com 
Mücâhid, İbn Abbas'in (ö. 68/687-688) önde gelen talebelerinden biridir ve Kur'an’ı İbn Abbas'a pek çok defa arzettiğine dair rivayetler nakledilmiştir. ${ }^{1}$ 102 (720), 103 (721) veya 104 (722) yılında vefat eden Mücâhid'in fiziki özelliklerine dair de önemli bilgiler gelmiştir. Mesela İbn Sa'd, Fitr b. Halîfe’nin (ö. 155/771 [?]) onu, saçı ve sakalları ağarmış vaziyette gördügünü, kendisini gören birinin onu eşeğini kaybetmiş bir hırpani (harbendec) zannettiğini nakletmiştir. $^{2}$

Mücâhid'in fakih, âlim, çok hadis nakleden sika bir râvi, kārî ve Kur'an’ı ve tefsiri en iyi bilen tâbiî olduğunda ittifak edilmiş; ${ }^{3}$ bizzat kendi dilinden "bütün ilmini Kur'an’a adadığı" nakledilmiş, "imam ve şeyhüll-kurrâ ve'lmüfessirîn” diye anılmıştır. ${ }^{4}$ Taberî (ö. 310/923), "Tefsirdeki İlmi Sebebiyle Övülen Kadim Selef Müfessirleri” başlı̆̆ı altında Mücâhid ile ilgili bazı bilgiler kaydetmiş, İbn Ebû Müleyke’den (ö. 117/735), "Mücâhid'i beraberindeki levhalarla, Kur'ân-1 Kerim tefsiri hakkında İbn Abbas'a soru sorarken gördüm; İbn Abbas ona 'Yaz!' diyordu, Mücâhid tefsirin tamamını ona sordu" rivayetini, Süfyân es-Sevrî̀den de (ö. 161/778), "Eğer tefsir Mücâhid’den gelmişse, o sana yeter"5 görüşlerini nakletmiştir. İbn Teymiyye (ö. 622/1225), Mücâhid'in tefsirine Şâfiî (ö. 204/820) ve Buhârî (ö. 256/870) gibi ehl-i ilmin itimat ettiğini, Ahmed b. Hanbel (ö. 241/855) gibi tefsirde eser tasnif edenlerin, Mücâhid'den gelen tarikleri diğerlerinden daha çok tekrar ettiklerini, onun "tefsirde bir âyet" olduğunu söylemiştir. ${ }^{6}$

Hakkındaki bu bilgiler yanında onun Kur'ân-1 Kerim'i rey ile tefsir etme eğiliminde olduğunu gösteren rivayetler de nakledilmiştir. Söz gelimi İbn Kuteybe (ö. 276/889), Irak âlimleri içinde reye ve kıyasa en sert tutumu gösterenin Şa bî (ö. 104/722), en müsamahalı olanın ise Mücâhid olduğunu söylemiş; A'meş’ten de (ö. 148/765) kendisinin şöyle dediğini rivayet etmiştir: "En faziletli ibadet, güzel görüştür” (er-re’yüll-hasen). ${ }^{7}$ İbn Teymiyye, Mücâhid bağlamında tâbiînin, sünnet ilmini aldıkları gibi tefsiri de sahabeden aldıklarını, bazı sünnetler konusunda istinbat ve istidlalle konuştukları gibi, tefsirde de bazan istinbat ve istidlal ile konuştuklarını dile getirmiştir."

\footnotetext{
1 İbn Sa'd, et-Tabakāt, VI, 19-20; İbn Hibbân, es-Sikāt, V, 419.

2 İbn Sa'd, et-Tabakāt, VI, 19-2O.

3 İbn Sa'd, et-Tabakāt, VI, 19-20; Buhârî, et-Târîhu’l-kebîr, VII, 411-12; İbn Ebû Hâtim, elCerh ve't-ta'dîl, VIII, 319; İbn Hacer, Tehzîbü't-Tehzîb, X, 44.

4 Zehebî, A 'lâmün-nübelâ', IV, 449-55.

5 Taberî, Câmiu'l-beyân, I, 90, 91.

6 İbn Teymiyye, Mukaddime, s. 10, 44.

7 İbn Kuteybe, Te’vîlü muhtelifi'l-hadîs, s. 109, 110.

8 İbn Teymiyye, Mukaddime, s. 10.
} 
Mücâhid'in Kur'an'ı rey ile tefsir etme eğilimi yanında, Kur'an'a veya Arap efsanelerine konu olan bir kısım yerleri araştırmaya gittiğine veya birtakım ilginç olaylar yaşadığına dair de rivayetler vardır. Ebû Nuaym el-İsfahânî (ö. 430/1038), tevil ve tefsir, görüş ve öğüt sahibi diye nitelendirdiği Mücâhid hakkında A'meş'ten, onun ne zaman hayret verici bir olay (u'cûbe) duysa, onu araştırmaya gittiğini, Hadramut'a Berhût Kuyusu'nu' ${ }^{9}$ görmek, Bâbil'e de Hârût ve Mârût hakkında bilgi sahibi olmak için gittiğini söylemiş, orada büyücü bir yahudi ile Hârût ve Mârût'u gördüklerini nakletmiştir. ${ }^{10}$ Zehebî de onun âhir ömründe Kûfe'de oturduğunu, çok yolculuk yapıp çok gezdiğini, bir cini yakalamaya çalışmak, bir erkeğin ölen karısıyla konuştuğunu duymak gibi yaşadığı bazı garip olayları nakletmiş, "Mücâhid’in ilimde ve tefsirde hoş karşılanmayan görüşleri ve gariplikleri” olduğunu söylemiştir. Bununla birlikte onun herhangi bir firkaya mensup olmadığını anlatan bir rivayete de yer vermiştir. ${ }^{11}$

Mücâhid'in diğer bir özelliği de kimi konularda Ehl-i kitaba bilgi sormasıdır. İbn Sa'd’ın rivayetine göre Ebû Bekir b. Ayyâş (ö. 193/809), A'meş'e, "Mücâhid'in tefsirinden niçin kaçınıyorlar?" diye sormuş; o da "Onun Ehl-i kitaba sorduğunu gördükleri için” cevabını vermiştir. ${ }^{12}$ A'meş’in tefsirine karşı mesafeli bir tutum takınılmasını, Ehl-i kitap âlimlerinden bilgi almasına bağladığı göz önüne alındığında, Mücâhid'in Ehl-i kitap’tan bilgi nakletmesi yönüyle de farklılık gösterdiği anlaşılmaktadır. Bu özelliği onun yukarıda sözü edilen araştırmacı kişiliğinin bir devamı niteliğinde değerlendirilebilir; zira o dönemin şartları düşünüldügüünde, Kur’an'da geçen kıssalardaki bazı unsurların anlaşılmasında, en önemli kaynak Ehl-i kitap’tır. Bununla birlikte, tefsire dair Mücâhid'den bu kadar çok rivayet gelmesi ve onun tefsirde muteber bir kaynak olarak görülmesi, A'meş'in, insanların onun tefsirinden uzak durdukları görüşünü şâz duruma düşürmektedir. Bu sebeple tefsirde Mücâhid'den nakledilen rivayetlerin ne kadarının Ehl-i kitap kaynaklı olduğunun bilahare araştırılması ve A'meş'in sözünün doğruluğunun tahkik edilmesi gerekmektedir.

Çağdaş dönem tefsir tarihi araştırmalarında da Mücâhid ile ilgili kimi görüşler ileri sürülmüştür. Goldziher (ö. 1921), Mu'tezile tefsirinden söz

9 Berehût veya Burhût diye de telaffuz edilmiş, meşhur bir vadi veya Yemen Hadramutu’nda inilmesi mümkün olmayan çok derin bir kuyu. Kâfirlerin ruhlarının mekânı olduğu söylenmiştir. Hz. Ali’nin, "Yeryüzündeki en kötü kuyu Berhût kuyusudur" dediği nakledilmiştir (Zehebî, A 'lâmü’n-nübelâ', IV, 456, neşredenin notu).

10 Ebû Nuaym, Hilye, III, 279, 280, 288.

11 Zehebî, A 'lâmü’n-nübelâ', VI, 454-55.

12 İbn Sa'd, et-Tabakāt, VI, 19-20. 
ederken, Mücâhid'i “Mu'tezile'den daha önce, Kiyâme sûresinin 23. âyetini mecaza hamleden erken dönem rivayet ekolünden bir müfessir" olarak takdim eder. ${ }^{13}$ Bilahare Mücâhid hakkında, "Kadim sika âlimler onun tefsirinin en sahih tefsir veçhi olduğunu kabul ederler" der. Rü’yetullah meselesinde, Mücâhid'in görüşünü naklettikten sonra, "Bu, Mücâhid'de gördügümüz, Kur'an’ı akılla tefsir etmenin tek örneği değildir” deyip yeri geldikçe zikredeceğimiz daha farklı örnekler verir. ${ }^{14}$

Fuat Sezgin (ö. 2018), Mücâhid'in, İbn Abbas'in yakın talebelerinden biri olduğunu belirttikten sonra şunu söyler:

Görünen o ki, Mücâhid aklî tefsirin ilk bağlılarından biridir. Onun tefsirinde pek çok mecaz ve teşbih ifadeleri vardır. Bazı tefsirleri ihtiyatla karşılanmıştır. Çünkü Mücâhid, pek çok defa hıristiyan ve yahudi âlimlerinden görüş almıştır. Fıkıh alanında ise hükümlerin tahricinde reye önem vermiştir. ${ }^{15}$

Bütün bu rivayet ve görüşlerden anlaşıldığı üzere, âlimlerin Mücâhid ile ilgili genel kanaati, onun öncelikle tâbiînden, sika, âlim ve kāri; İbn Abbas'in talebesi olması hasebiyle tefsir ve Kur'an ilimlerinde üstün bir otorite olduğu noktasında birleşmektedir. O, bütün hayatını Kur’an'a ve tefsir ilmine adamış, kendi döneminin pek çok âliminin dile getirdiği gibi, tefsirde üstün bir mevki elde etmiştir. Bu nitelikleri ve tefsirdeki engin bilgisi sebebiyle tefsir ilminin en önemli kaynaklarından biri olmuş; Buhârî, el-Câmiu's-sahîh'inde, Taberî, Câmiu'l-beyân'inda onun tefsirlerine önem vermişlerdir. Sadece onlar değil, Sezgin'in ifadesiyle hemen bütün müfessirler onun tefsirlerini nakletmişlerdir. ${ }^{16}$

Bu özellikleri yanında Mücâhid, tâbiîn âlimleri arasında özellikle rey ve içtihada önem vermesiyle ön plana çıkmıştır. İbn Teymiyye’nin "istinbata ve istidlale dayalı görüşler" diye nitelendirdiği, ${ }^{17}$ Zehebînin, "Tefsirde hoş karşılanmayan görüşleri vardır" dediği, ${ }^{18}$ onun bu tür yorumları olmalıdır. Çağdaş dönem araştırmacıları bunun adını "aklî tefsir" veya "tefsirde aklî eğilim” diye koymuşlardır. Buna göre Mücâhid, zamanla belirginleșecek olan

\footnotetext{
13 Goldziher, Mezâhib, s. 127.

14 Goldziher, Mezâhib, s. 129.

15 Sezgin, Târîhu't-türâsi'l-Arabî, I, 70, 71.

16 Sezgin, Târîhu't-türâsi'l-Arabî, I, 56 .

17 İbn Teymiyye, Mukaddime, s. 10.

18 Zehebî, A 'lâmün-nübelâ’, VI, 455 .
} 
tevil yönteminin veya aklî tefsirin öncü isimlerinden biri olmaktadır. ${ }^{19} \mathrm{Bu}$ özelliği ile o, bir kısım müfessire ilham kaynağı olmakla birlikte, onun tefsirine itimat edip tefsirlerinde görüşlerini nakleden müfessirlerin eleştirilerine maruz kalmıştır. Ama bahse konu özellikleri onun tefsirde bir otorite olarak görülmesini ve güvenilirliğini hiçbir şekilde zedelememiştir. Bu makalede, Mücâhid'in bazı âyetlere getirdiği aklî yorumlar ele alınıp rivayetlerin çoğunun kaynağ1 olan Taberî başta olmak üzere müfessirlerin onun söz konusu yorumları üzerindeki kanaatleri tahkik edilecektir.

\section{A) Erken Dönemde Tevil}

Mâtürîdînin tefsir ve tevil arasındaki farkı anlatırken, tefsirin sahabeye ait olduğu, bunu da onların Kur'an'ın hakkında indiği olaylara şahitlik etmelerine bağladığ 1 , tevilin ise fukahaya (âlimler) ait olduğu, zira tevilde sözün farklı vecihlerinden birine tevcih edildiği dolayısıyla tevilde, tefsirdeki gibi bir kesinlikten söz edilemeyeceği görüşünde olduğu kaydedilmiştir. ${ }^{20}$ Tevil ve tefsir ayırımı ile ilgili dile getirilen diğer farklar ve benzerlikler bir yana, Mâtürîdîye nispet edilen bu ayırımda dikkat çeken en önemli husus, tefsirin sahabeye, tevilin ise onlardan sonraki nesillere tahsis edilmesidir. Bu tasnife göre, tâbiînin de dahil olduğu neslin, sahabeden naklettikleri dişındaki bütün görüşleri tevil kategorisinde olup tevil tâbiînle birlikte başlamıştır.

Aslında bu genel tefsir-tevil ayırımının içinde daha özel bir tevilden veya âyetlerin mecaza hamledilme olgusundan söz etmek gerekmektedir. Mesela İbn Abbas'ta, Mâtürîdînnin sahabe için çizdiği tefsir tasnifini aşan tevil örneklerine rastlanabilmekte, tâbiînin bu örnekleri daha ileri noktalara taşıdığı görülmektedir. Nitekim Sezgin, tefsirin teşekkül sürecinden bahsettiği bölümde, tefsirin İbn Abbas ve talebelerinin döneminde çok hızlı ve güçlü bir gelişim gösterdiğini, bütün bunların yanı sıra, Kur'an’ın özgür tefsirinden kaçınmalarının mümkün olmadığı bu dönemde, rey prensibini tefsire soktuklarını ve bunu uyguladıklarını ifade etmektedir. Bu bağlamda Mücâhid'i de zikreden müellif, onun özgür tefsir noktasında çok ileri boyutlara ulaştığını, onda müphem ifadelerle mecazi tevilin ilk örneklerinin görüldüğünü belirtmektedir. ${ }^{21}$

19 Goldziher, Mezâhib, s. 127, 130; Sezgin, Târîhu't-türâsi'l-Arabî, I, 70. Işıcık da onun bu yönünü şöyle ifade eder: "İslam'da ilk rasyonel tefsirleriyle tanınan ünlü tâbiî müfessir Mücâhid...” (Işıcık, Kur'an’ı Anlamada Temel Bir Problem, s. 56).

20 Mâtürîdî, Tévîlât, I, 349.

21 Sezgin, Târîhu't-türâsi'l-Arabî, I, 60. 
Henüz tevil, mecaz gibi kavramlar tedavüle girmemiş olsa da İbn Abbas, kimi âyetleri mecazi anlamıştır. O, Hz. Ali’nin elçisi olarak görev ald1ğ 1 Hâricîler'le tartışmalarında, her ne kadar Hz. Ali, "Onlarla tartış fakat Kur'an'la delil getirme, çünkü Kur'an çok yönlüdür; onlarla sünnetle tartış!"22 demiş olsa da o buna mecbur kalmış ve Kur'an'daki çok anlamlılığa dikkat çekip Hâricîler'in Kur'an’n anlamlarını idrak etmekteki acziyetlerini dile getirmiştir. ${ }^{23}$ İbn Abbas'a Hâricîler'den ve Kur'an'dan bazı âyetleri dinlerken hissettikleri huşûdan söz ettiklerinde, onun şöyle dediği rivayet edilmiştir: "Onlar muhkemine inanıyorlar fakat müteşâbihe gelince helak oluyorlar."24

İbn Abbas'in, yahudiler, hıristiyanlar ve o dönemde ortaya çıkan Hâricîler gibi fırkalarla mücadelenin şiddetlendiği ve tartı̧ma alanının genişlediği bir ortamda bazı âyetleri tevil ettiğine dair rivayetler gelmiştir. Bu âyetlerden biri "kürsî âyeti" 25 olup İbn Abbas’n "kürsî"yi "Allah’n ilmi" ile tefsir ettiği nakledilmiştir. ${ }^{26}$ Böylelikle o, Allah’ın beşere benzemediğini ve bir mekânda yer tutmadığını ifade eden bir tevilde bulunmuştur. ${ }^{27}$

İbn Abbas'in, sonraki dönemlerde haberî sıfatlar olarak isimlendirilecek ve tevile konu olacak olan bazı meselelerde de tevile gittiğine dair görüşler nakledilmiştir. "Her nerede olursanız olun, O sizinle beraberdir"28 âyetindeki "maiyyet"e o, "Sizi her yerde bilir"29 anlamı vermiş, muhtemelen Allah Teâlẩnın gökte olduğunu bildiren naslarla bu âyet arasında ortaya çıkabilecek teâruzu ortadan kaldırmak istemiştir. ${ }^{30}$

Taberî, "Allah göklerin ve yerin nurudur"31 mealindeki âyeti, "Allah gökler ve yerdekileri hidayete erdirendir; onun nuru ile hakka ulaşırlar, onun hidayetiyle dalalet şaşkınlığından kurtulurlar” şeklinde tefsir etmiş, bunu da İbn Abbas'in "Allahu hâdî ehli’s-semâvâti ve'l-ard" (Allah göklerdeki ve yerdekileri hidayete erdirendir) şeklindeki rivayetine dayandırmıştır. Âyetin devamında gelen, "Size apaçık deliller, sizden önceki yaşayanlardan bir misal

22 Süyûtî, el-ìtkān, II, 145 .

23 Ebû Zeyd, el-İtticâhül-aklî, s. 95, 96.

24 Taberî, Câmiu'l-beyân, VI, 198; Ebû Zeyd, el-İtticâhü'l-aklî, s. 96.

25 el-Bakara $2 / 255$.

26 Taberî, Câmiu'l-beyân, V, 397 .

27 Ebû Zeyd, el-İtticâhü̉l-aklî, s. 96. İbn Abbas'tan “kürsî”nin, “Rahman’ın iki ayağını koyduğu yer" anlamına gediğine dair bir görüş de nakledilmiştir (İbn Ebû Hâtim, Tefsîr, II, 491). Taberî ise bu görüşü İbn Abbas dişında Ebû Mûsâ ve birtakım tâbiîn âlimlerine isnat eder (Taberî, Câmiu'l-beyân, V, 398, 399).

28 el-Hadîd 57/4.

29 Ahmed b. Hanbel, Kitâbü's-Sünne, I, 306.

30 Mavil, Mâtürîdî Kelâmında Tévil, s. 320, 321.

31 en-Nûr $24 / 35$. 
ve müttakiler için bir öğüt indirdik" ifadelerini de, "Böylelikle de sizi hidayete erdirdik..." cümleleriyle tefsir ederek buna delil getirmiştir. ${ }^{32}$

Taberî, muhkem-müteşâbih ayırımından söz eden âyetlerin tefsirinde de İbn Abbas'tan şöyle bir rivayet nakletmiştir: "Muhkemât Kur'an'ın nâsihi, helali, haramı, hadleri, farzları gibi iman edilen ve amel edilen şeylerdir. Müteşâbihat ise mensuhu, mukaddem ve muahharı, meselleri ve kasemleri (gibi) iman edilip amel edilmeyen şeylerdir." 33 İbn Abbas, muhkemden helali ve haramı tayin edip teşrîe konu olan ahkâm âyetlerini, müteşâbihten ise ister sadece tilavet için Kur'an'da bırakılan mensuh ister ahkâm âyetleri dışındaki âyetler olsun teşrîe konu olmayan âyetleri anlamıştır. İbn Abbas, mukaddem, muahhar, emsal ve kasemi müteşâbihin içine dahil etmiştir ki bunların hepsi Ebû Ubeyde (ö. 209/824 [?]), Ferrâ (ö. 207/822), Câhiz (ö. 255/869) ve İbn Kuteybe gibi âlimlerin mecazın içine dahil edecekleri üslup olgularıdır. İbn Abbas, muhkem ve müteşâbih ayırımını bu şekilde yaptıktan sonra, kendisi hakkında tabii olarak şunu söyleyebilecektir: "Ben onun tevilini bilenlerden biriyim." 34

İbn Abbas ile ilgili bu nakiller göstermektedir ki, tefsirin ilerleyen dönemlerinde yaygınlaşacak olan tevil veya tefsirde rey meselesinin ilk örnekleri, sahabeden İbn Abbas'a kadar uzanmaktadır. Bu örnekler bize bir taraftan erken dönemde, adı konulmamış olsa da kimi âyetlerin tevil edildiğini gösterirken, bir taraftan da haberî sıfatların anlaşılmasında Selef'e nispet edilen tefviz ve tenzih anlayışının yekpare bir bütünlük arz etmediğini ortaya koymaktadır. Meseleye tefsir ilmi merkezinden bakıldığında, tefsirde reyin ve içtihadın sosyal ve fikrî hayattaki hızlı değişimin getirdiği birtakım etkenlerle sahabe ve tâbiîn ile birlikte ortaya çıktığını ve bunun Mücâhid gibi tâbiîn âlimlerinde biraz daha görünür hale geldiğini söylemek mümkündür.

\section{B) Mücâhid'in Tevilleri ve Aklî Yorumları}

\section{Tevil: Müteşâbihlerin Anlamları Bilinebilir mi?}

İbn Abbas’ın, müteşâbihlerle ilgili söylediği, "Ben onun tevilini bilenlerdenim"35 sözü Mücâhid'den gelmektedir. Esasen İbn Abbas'in, muhkem ve müteşâbihin anlatıldığ 1 Âl-i İmrân sûresinin 7.âyetinde, İbn Mes' ûd (ö. 32/652653), Übey b. Kâ‘b (ö. 33/654 [?]) ve Hz. Âişe (ö. 58/678) gibi sahâbîlerle birlikte إلَّا إلَّ ibaresi üzerinde vakfettiği ve müteşâbihlerin anlamlarının

32 Taberî, Câmiu'l-beyân, XIX, 177, 178; Mavil, Mâtürîdî Kelâmında Te’vil, s. 376, 377.

33 Taberî, Câmiu'l-beyân, VI, 175.

34 Taberî, Câmiu'l-beyân, VI, 203; krş. Ebû Zeyd, el-İtticâhü'l-aklî, s. 144.

35 Taberî, Câmiu'l-beyân, VI, 203. 
bilinemeyeceği kanaatinde olduğu, ${ }^{36}$ dolayısıyla yalnızca Mücâhid'den gelen, müphem ve mutlak olan bu görüşün naklî bir delil olamayacağı ileri sürülmüştür. ${ }^{37}$ Bununla birlikte, şayet yukarıda zikrettiğimiz Taberînin naklettiği İbn Abbas'ın muhkem-müteşâbih ayırımı ve mütaşâbihe çizdiği çerçeveyi anlatan rivayetin doğruluğu kabul edilecekse, onun bu tür âyetlerin tevilini bildiği iddiası da kabul edilecektir. İbn Kesîr (ö. 774/1373), lafza-yi celâlde vakfedenlerin, âyetteki "tevil" kelimesine, bir şeyin vukuu veya âkıbeti anlamını verdikleri ve bunun ancak Allah tarafından bilindiğine; devamındaki ibaresinde vakfedenlerin ise “tevil”e tefsir anlamı verdikleri ve bunun da ilimde rüsuh sahiplerinin bilebileceği kanaatinde olduklarına dikkat çekmiştir. ${ }^{38}$ Bu görüşten hareketle, İbn Abbas'in âyeti her iki veçhe göre anladığını; birincisine göre tevile "âkıbet" anlamı verip bu âyetlerin anlamlarını Allah'tan başka kimsenin bilemeyeceği, ikincisine göre "tefsir" anlamı verip bu tür âyetlerin tefsirini rüsuh sahibi âlimlerin de bilebileceği kanaatinde olduğunu düşünmek gerekecektir. Böylelikle Mücâhid onun ikinci görüşe göre hareket ettiği bilgisini nakletmiş olacaktır.

İbn Abbas, ikinci görüşte olsun veya olmasın, burada bizim için mühim olan Mücâhid'in sonraki ibare üzerinde vakfettiği ve râsih âlimlerin müteşâbihleri bilebildiği kanaatinde olduğudur. Nitekim Taberî, Mücâhid’in açıkça bu görüşte olduğunu iki ayrı tarikten nakletmiştir: "ílimde derinleşenler onun tevilini bilirler ve 'Biz ona iman ettik' derler." 39 Onunla birlikte Rebî‘ b. Enes (ö. 139/756-757) ve Muhammed b. Ca‘fer b. Zübeyr de (ö. 110-120/728-737[?]) bu görüşü benimsemişlerdir. ${ }^{40}$ Ancak görünen o ki, Mücâhid bu görüşün de öncülügünü üstlenmiş ve muhtemelen bu tevcihiyle müteşâbih âyetlerin tevilinin kapısını aralamak istemiştir.

Taberî, yukarıda yer verdiğimiz İbn Abbasın tanımından farklı olarak muhkemlere, "Allah’ın helalini ve haramını muhkem bir şekilde beyan ettiği", müteşâbihlere de "lafızları farklı olsa da mânaları birbirine benzeyen" âyetler anlamını verenler de olduğunu söylemiştir. Bu görüşü de İbn Ebû Necîh (ö. 130/747-748) yoluyla iki ayrı tarikten Mücâhid’e nispet etmiştir. Buna göre Mücâhid, muhkem ve müteşâbihin çerçevesini "Muhkemât, helaller ve haramlarla ilgili âyetlerdir; bunun dışındakiler müteşâbihler olup birbirlerini tasdik ederler" şeklinde çizmiştir. Buna da şu âyetleri örnek vermiştir: "O

\footnotetext{
36 Taberî, Câmiu’l-beyân, VI, 199.

37 Işıcık, Kur'an’ı Anlamada Temel Bir Problem, s. 57.

38 İbn Kesîr, Tefsîr, II, 11, 12.

39 Taberî, Câmiu’l-beyân, VI, 203.

40 Taberî, Câmiu’l-beyân, VI, 203-204.
} 
ancak fâsıkları saptırır"; 41 "Allah inanmayanlara azabı işte böyle verir"; 42 "Allah doğru yolu bulanların hidayetini arttırır ve onlara takvalarını verir."43 Buhârî "Kitâbü't-Tefsîr"de, muhkem-müteşâbih meselesine ayırdığı babda muallak olarak Mücâhid'in bu görüşüne aynıyla yer vermiş, devamında da, “İlimde derinleşenler' (onun tevilini) bilirler ve 'Biz ona iman ettik derler" görüşünü kaydetmiştir. ${ }^{44}$

Allah Teâlẩnın inançsızları veya günahkârları saptırıp inananları ise takviye ettiğini anlatan bu âyetlerin, kader, irade hürriyeti ve cebir gibi kelamî tartışmalarda argüman olarak kullanılan âyetler olması dikkat çekicidir. Mücâhid'in ibadet ve muamelatın dışında, itikadî bir muhtevaya sahip olan bu tür âyetlerin bir şekilde tevilini muhtemel gördüğü anlaşılmaktadır. ${ }^{45} \mathrm{Her}$ ne kadar Mücâhid'de henüz sistematik bir tevil ve mecaz anlayışı yoksa da onun birtakım âyetleri tevil etme eğiliminde olduğu görülmektedir.

Şimdi Mücâhid’e nispet edilen tevil örnekleri üzerinden onun söz konusu eğilimiyle ilgili tartışmalara geçebiliriz.

\section{Mesh: Sahil Şehri Maymuna Dönüştürüildü mü?}

Mücâhid'in hakikati mecaza hamlettiği, diğer bir deyişle kendisine nispet edilen en meşhur aklî tefsir örneği, onun Ashâbüs-sebt'in uğradığ azapla ilgilidir. Âyet-i kerîmede, "İçinizden, cumartesi yasağını çiğneyenleri ve bu yüzden kendilerine, 'Aşağılık maymunlar olun!' dediğimizi iyi biliyorsunuz. Biz bunu hem o günkülere hem de sonra geleceklere caydırıcı bir ibret ve Allah'a karşı gelmekten sakınanlara (müttakiler) bir ögüt kılmıştık"46 buyurulur. Taberî, bu âyetin tefsirinde İbn Ebû Necîh yoluyla iki ayrı tarikten Mücâhid'in şöyle dediğini nakleder: "Onlar mesh edilmediler (gerçekten maymuna çevrilmediler); bu sadece Allah Teâlẩnın onlar hakkında verdiği bir misaldir. Tipkı (Cuma sûresinde) kitap taşıyan merkepler misalini verdiği gibi"." ${ }^{77}$ Taberî Mücâhid'den, "Kalpleri çevrilmiștir; kendileri maymuna çevrilmemiştir..." şeklinde meseleyi daha açıklayıcı bir başka rivayet daha nakleder. ${ }^{48}$ İbn Ebû Hâtim de (ö. 327/938) yine İbn Ebû Necîh yoluyla,

\footnotetext{
41 el-Bakara 2/26.

42 el-Enâm 6/125.

43 Muhammed 47/17; Taberî, Câmiu'l-beyân, VI, 177.

44 Buhârî, "Tefsîr", $3 / 58$.

45 Ebû Zeyd, el-İtticâhüll-aklî, s. 145, 146.

46 el-Bakara 2/65, 66.

47 Taberî, Câmiu'l-beyân, II, 172.

48 Taberî, Câmiu'l-beyân, II, 172, 173.
} 
Taberînin yer verdiği tariklerin birinden bu rivayeti nakletmiştir. ${ }^{49}$ Aynı rivayet Mücâhid'e nispet edilen tefsirde, yine İbn Ebû Necîh yoluyla farklı bir tarikten şöyle nakledilir: "Maymuna çevrilmemişlerdir; fakat bu Allah Teâlẩnın ‘Onların durumu kitap taşıyan merkepler gibidir’ sözüne benzer." ${ }^{50}$

Bilindiği gibi Taberînin tefsirde gözettiği temel ilkelerden biri, âyetin hamledildiği mânanın, Kur’an'dan başka bir delil veya özel sebepler olmadığ sürece, Kur'an’nn zâhirine aykırı olmamasıdır. ${ }^{51}$ Taberî, her ne kadar tefsirinde kendisine fazlasıyla itimat etse de, "Mücâhid'in bu görüşünün, Allah’ın kitabının delalet ettiği açık anlama (zâhir) aykırı bir görüş" olduğunu söylemekten geri kalmamıştır. Bu görüşünü, Allah Teâlẩnın Kư'an'da İsrâiloğulları̉nı, Allah’ı açıç̧a görmek istemeleri ve buzağıya tapmaları gibi kimi aşırı davranışları sebebiyle cezalandırdığını haber verdiğini, bir kimsenin Allah onları maymuna çevirmemiştir demesiyle, söz konusu diğer cezaların vuku bulmadığını söylemesinin aynı şey olduğu çıkarımıyla desteklemiştir. Ona göre bunları kabul edip diğerini kabul etmemek için delil gerekir. Ondan aralarındaki farkı tespit için bir haber veya sahih bir hadis istenir. Ayrıca Mücâhid'in bu görüşü, hata ve yalanda icmâ etmeleri caiz olmayan bütün otoritelerden (cemîu'l-hucce) ittifakla nakledilen görüşe aykırıdır. Bir görüşün hatalı veya bozuk olduğuna, onun icmâa aykırı olması yeterli bir delildir. ${ }^{52}$

Görüldüğü gibi Taberî, İsrâiloğulları̉nın işledikleri pek çok günahın karşılığında cezalandırıldıkları gibi, cumartesi yasağını da çiğnedikleri için cismani olarak maymunlara dönüştürülerek cezalandırıldıklarını, bunlardan bir kısmını kabul edip bir kısmını reddetmenin tutarlı olmayacağını söylemektedir. Taberînin öne sürdüğü en önemli kanıt ise Mücâhid’den gelen bu görüşün Selef'ten gelen diğer görüşlere, kendi ifadesiyle icmâa aykırı olmasıdır.

49 İbn Ebû Hâtim, Tefsîr, I, 133.

50 Mücâhid, Tefsîr, s. 205. İbn Ebû Hâtim, yine İbn Ebû Necîh yoluyla Mâide sûresinin 60 . âyetinin tefsirinde Mücâhid'in, "Yahudilerden bir kısmı meshedilmiştir" șeklinde bir görüş nakletmiştir (İbn Ebû Hâtim, Tefsîr, IV, 1164-1165). Yukarıda verdiğimiz rivayetle bu rivayet arasında görünen çelişki hakkında şu ihtimaller akla gelmektedir: 1. Burada Mücâhid'in görüşü eksik nakledilmiş gibidir. Çünkü diğer rivayetlerde, "Kalpleri meshedilmiştir..." denilirken burada sadece "meshedilmiştir" denilmiştir. 2. Mücâhid Taberî ve İbn Ebû Hâtim'in naklettiği manevi mesh görüşündedir. Burada ise mesh edilenlerin yahudilerden bir toplum olduğunu izah etmek istemiş, bir meshin olduğunu söylemiş ancak mahiyetine dair herhangi bir kanaat belirtmemiştir. Neticede meshin varlığını Mücâhid de kabul etmekte, sadece manevi bir mesh olduğu noktasında diğer müfessirlerden ayrılmaktadır. 3. Mücâhid'in bu görüşünden maddi mesh anlaşılması durumunda, Taberînin iki ayrı tarikten, İbn Ebû Hâtim'in yine bu tariklerden biriyle Mücâhid'e manevi meshi isnat etmesi, Mücâhid'e nispet edilen tefsirde de aynı görüşün nakledilmesi, ikinci görüşü zayıflatmaktadır.

51 Goldziher, Mezâhib, s. 110-11.

52 Taberî, Câmiu'l-beyân, II, 65 . 
Esasen Mücâhid, bu görüşüyle İsrâiloğlulları’nın bir cezaya çarptırıldığını reddetmiş değildir. Onun görüşü bütünüyle cezanın mahiyetiyle ilgilidir. Taberînin ikinci rivayetinin de işaret ettiği gibi Mücâhid, onların kalplerinin dönüştürüldüğünü ifade ederek insan suretinde olsalar bile huy ve karakter olarak aşağılık maymunlar gibi davrandıklarını, hiçbir öğüde kulak asmayıp hiçbir ikazı dikkate almayacak bir ruh haline sahip olduklarını anlatmış olmaktadır. Bu da aslında onların insan haysiyetini yitirip aşağılık bir seviyeye düştüklerini ve cezanın bu şekilde tahakkuk etmiş olduğunu göstermektedir. Dolayısıyla Taberînnin bu yöndeki itirazından ziyade Mücâhid'in öne sürdügü bu görüşün Kur’an’n zâhirine ve icmâa aykırı olduğu için reddedilmesi daha uygun olmalıdır.

Yukarıda yer verildiği gibi, Mücâhid'in İsrâiloğulları̉ndan çokça bilgi aldığına dair rivayet dikkate alındığında, "Acaba Mücâhid bu görüşü, İsrâiloğulları’ndan aldığı bir bilgiye dayalı olarak benimsemiş olabilir mi?" diye bir soru akla gelmektedir. Söz konusu cezanın maddi olduğunu düşünen ve tefsirinin çeşitli yerlerinde Tevrat'tan nakillerde bulunan Safedî (ö. 764/1363), “Bu bilgi Tevrat'ta niçin geçmemiştir?” sorusuna şöyle cevap vermektedir: "Bu olay ya Tevrat'ın nüzulünden sonra olmuştur ya da onların Tevrat'tan çıkardıkları ve değiştirdikleri kısımlardandır." ${ }^{53}$ Buna göre olay Tevrat'ta anlatılmamıştır. Câhiz'in beyanına göre, Ehl-i kitap, insanların maymuna ve domuza dönüştürüldügünü kabul etmemekte; sadece Lût'un eşinin taşa dönüştügünü söylemektedirler. ${ }^{54}$ Bununla birlikte olayın hangi şehirde ve nasıl meydana geldiğini anlatan uzun rivayetler ${ }^{55}$ ve Kur'an'daki, "Siz biliyorsunuz" ifadesi olayın şifahi olarak İsrâiloğulları arasında yaşadığını göstermektedir. Dolayısıyla Mücâhid, Ehl-i kitap’tan aldığı bir bilgiden ziyade kendi dirayetiyle, bunun bir ceza ve ibret olabilmesi için maddi olarak maymuna dönüştürülmüş olmalarını zorunlu görenlerin aksine, insan oldukları halde maymunlar gibi hareket eden kimselerin çok daha ciddi bir cezaya çarptırılmış olacağını ve daha çok ibret olacaklarını düşünmüş olmalıdır. Mesela adı geçen Safedî, "Günümüzde yahudiler, suret olarak olmasa da anlam olarak bu seviyededirler" ${ }^{26}$ demek suretiyle yahudilerde böyle bir karakter olduğunu dile getirmiştir. ${ }^{57}$

53 Safedî, Keşfü̉l-esrâr, I, 134.

54 Câhiz, Kitâbü'l-Hayevân, IV, 313. İbn Âşûr da ibret olması bakımdan birinci görüșün daha açı olduğunu belirtmekle birlikte, tarihe ikincisinin daha yakın olduğunu çünkü İbrânî tarih kitaplarında bu olayın nakledilmediğini söylemektedir (İbn Âşûr, etTahrîr, I, 544).

55 Taberî, Câmiu'l-beyân, II, 167-72.

56 Safedî, Keş̧ü̉l-esrâr, I, 134.

57 Mesh konusunda ayrıntı için bk. Coşkun, “Mesh”, s. 303-304. 
Goldzihere göre Mücâhid, bu görüşüyle Mu'tezile âlimlerinin bile cesaret edemedikleri bir görüşü benimsemiştir. Zira onlar maddi bir mesh olduğu konusunda herhangi bir şüpheye kapılmaksızın, meshin yorumunda -iklim şartlarının etkisiyle bunun mümkün olduğu gibi- makul görüşler ileri sürmüşlerdir. Nitekim Nazzâm (ö. 231/845), Hişâm b. Hakem (ö. 179/795) ve Ebû Bekir el-Esam (ö. 200/816) gibi âlimler maddi meshi mümkün görmüşlerdir. ${ }^{58}$ Goldziher ayrıca Zemahşerînin (ö. 538/1144) kendi eğilimine oldukça uygun olan bu görüşe hiç iltifat etmemiş olmasının da garipsenecek bir durum olduğunu belirtmektedir. ${ }^{59}$

Görünen o ki, Mu'tezilî âlimler de dahil Mücâhid'in bu görüşüne çok fazla iltifat edilmemiştir. Mesela Mâtürîdî, Mücâhid’in görüşünü zikretmeksizin biri, "onlardan kökten insaniyetin giderilmesi" diğeri de, "onlarda akıl ve idrak gibi insanî özellikler ibka edilmekle birlikte, cevherleri maymun cevherine dönüştürülmüştür” şeklinde iki görüş zikretmiştir. Mâtürîdî, bütün insaniyetleri giderilseydi bunu anlayamazlar ve başlarına gelene üzülemezlerdi; kendilerine verilen cezayı bilmeleri ve kendilerinin Allahin yarattığı en çirkin ve en vahşi mahluk olduğunu görmeleri için ikincisinin daha doğru olduğu görüşünü benimsemiştir. ${ }^{60}$ Fahreddin er-Râzîye (ö. 606/1210) göre dilde bu tür mecazi kullanımlar olmakla birlikte, mesh caizdir ve âyeti zâhirine göre anlamak mümkündür. Her ne kadar Mücâhid'in görüşü çok uzak bir ihtimal değilse bile, böyle bir tevile gitmeye ihtiyaç yoktur. ${ }^{61}$ İbn Kesîr ise İbn Ebû Hâtim ve Taberîden Mücâhid'in görüşünü naklettikten sonra Taberînnin senedlerini vermiş, "Bu Mücâhid’den gelen sağlam bir seneddir (senedün ceyyid), ne var ki buradaki ve başka yerlerdeki siyakın zâhirine aykırı ferd (garib) bir görüştür" değerlendirmesinde bulunmuştur. ${ }^{62}$ İbn Kesîr diğer görüşleri naklettikten sonra, "Bahse konu âlimlerin görüşlerinden maksat, meshin şeklî (sûrî) değil, manevi olduğunu benimseyen Mücâhid'in görüşüne aykırıdır; aksine doğru olan manevi-şeklî olmasıdır” demiştir. ${ }^{63}$ İbn Kesîr bu görüşüyle, yukarıda yer verilen onların şeklî olarak maymuna çevrildiklerini fakat akıllarının ve idraklerinin insan olarak kaldığını kastetmiş olmalıdır. ${ }^{64}$

58 Goldziher, Mezâhib, s. 130.

59 Goldziher, Mezâhib, s. 130; krş. Câhiz, Kitâbüll-Hayevân, IV, 295-97.

6o Mâtürîdî, Te’vîlât, I, 488.

61 Fahreddin er-Râzî, Mefâtîhu'l-gayb, III, 541.

62 İbn Kesîr, Tefsîr, I, 289.

63 İbn Kesîr, Tefsîr, I, 291.

64 Reşî̀ Rızâ, “Bununla kastı nedir?” diye bir soru sormuş fakat cevabını vermemiştir (Reşîd Rızâ, Tefsî̀ül-Menâr, I, 286). 
Klasik dönemde durum bu şekilde olmakla birlikte modern dönemde akılcı eğilimlerin güç kazanmasıyla Mücâhid'in görüşü fazlasıyla ön plana çıkartılmış ve önemli sayıda müfessir tarafından benimsenmiştir. Mesela Muhammed Abduh (ö. 1904), cumhûr-1 ulemanın âyeti hakiki anlamda yorumladıklarını, ne var ki âyetin bu konuda bir nas olmadığını, geriye nakillerin kaldığını, şayet bunlar sahih olsaydı âyetin asiler için bir ibret ve ögüt olmayacağını söyleyip bunu da şöyle gerekçelendirmiştir:

Çünkü onlar yakinen biliyorlar ki Allah her günahkârı insanlıktan çıkarmak suretiyle mesh etmemektedir. Zira bu onun yaratma yasalarından biri değildir. Geçmiş milletler hakkındaki yasalar hakkında bilinecek en büyük ibret, Allah’’n emrinden çıkıp onun belirlediği yoldan sapan kimselerin insan mertebesinden düşüp dilsiz hayvanlara katılmalarıdır. ${ }^{65}$

M. Reşîd Rizâ (ö. 1935) A'râf sûresinin tefsirinde kendisinin de manevi meshi tercih ettiğini, Mücâhid'in görüşünü reddeden Taberîye itibar edilemeyeceğini, İbn Abbas ve cumhurdan gelen görüşü tercih etmesinin onun içtihadı olduğunu söylemiştir. ${ }^{66}$

Mücâhid benzer bir ifadeyi, Hz. İbrâhim'e ölülerin nasıl diriltildiğini anlatan, "Sonra onlardan (kuşlar) bir parçayı her dağa bırak" 67 âyetinin tefsirinde de kullanmıştır: "Onları parça parça her dağa bırak. Sonra onları kendine çağır; süratle sana geleceklerdir. İște Allah ölüleri böyle diriltir. $\mathrm{Bu}$, Allah’ın İbrâhim’e verdiği bir misaldir." ${ }^{38}$ Taberî Mücâhid'in buradaki temsille neyi kastettiği üzerinde durmaksızın, onun dört kuşun uzuvlarını paramparça ettikten sonra nübüvveti döneminde ulaşabildiği bütün dağlara bu kuşların parçalarını atma emrine muhatap olduğu yorumunu tercihe değer bulmuştur. ${ }^{69}$ Mücâhid'in buradaki temsilden kastı sarih değildir. Bununla birlikte, onun "fe-surhünne ileyk" lafzını "kattı hünne" (kesip parçala $)^{70}$ şeklindeki tefsirinden anlaşılan o ki Mücâhid âyetten hakikaten kuşların parçalanmasını anlamış, temsille de Allah Teâlẩnın kuşlarla Hz. İbrâhim’e ölüleri nasıl dirilttiğini göstermek, böylelikle soyut bir tasavvuru, müşahhas bir örnekle ve bizzat İbrâhim'in eliyle gerçekleştirmek istediğini

65 Reşîd Rizâ, Tefsîrüll-Menâr, I, 285.

66 Reşîd Rızâ, Tefsîrül-Menâr, VI, 317. Muhammed Esed de aynı görüşü benimsemiştir

(Esed, Kur'an Mesajı, s. 307, 308).

67 el-Bakara 2/260.

68 Taberî, Câmiu'l-beyân, V, 508.

69 Taberî, Câmiu'l-beyân, V, 509.

70 Taberî, Câmiu'l-beyân, V, 503. 
kastetmiştir. ${ }^{71}$ Nitekim İbn Abbas’ın da söz konusu ifadeyi, "Bu bir misaldir" dedikten sonra kuşların dörder parçaya bölünüp dağlara atılması şeklinde anladığı görülmektedir. ${ }^{72}$ Dolayısıyla Mücâhid burada, daha sonra Ebû Müslim el-İsfahânî (ö. 322/934) tarafından dile getirileceği gibi bir mecaza gitmemiştir. Bilindiği üzere Ebû Müslim el-İsfahânî, bu âyeti hakikaten kuşların parçalara bölünüp atılması olarak değil, "fe-surhunne ileyk" lafzının "kuşları eğitip çağrıya cevap vermeye alıştırması ve kuşlardan her birini bir dağa bırakıp sonra çağırması” şeklinde anlamıştır. Bundan da amacın, ruhların bedenlere dönüşünün kolaylıkla olacağına dair "somut bir misal vermek" olduğunu söylemiştir. ${ }^{73}$

\section{Livata: Kur'an Eşcinsellere Ceza Öngörüyor mu?}

Doğrudan aklî bir tefsir örneği olmasa da Mücâhid'in farklı ve genellikle adıyla özdeşleșen yorumlarından biri de Nisâ sûresinin 16. âyeti hakkındaki yorumudur. Söz konusu âyette, "İçinizden o hayâsızlığı işleyen iki kişiyi de cezalandırın. Eğer o iki kişi tövbe edip kendilerini düzeltirlerse onları bırakın; şüphe yok ki Allah, tövbeleri geri çevirmeyen ve merhametinde sınır

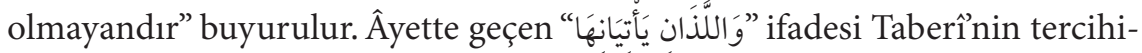
ne göre, zina eden erkeğe ve kadına hamledilmiş, evli kadınlara hamledilen bir önceki âyetten farklı olarak burada bekâr erkeklerden ve kızlardan söz edilmiştir. Mücâhid ise söz konusu ifadeye, "zina eden iki erkek" anlamı vermiştir. $^{74}$

Taberîye göre âyette kastedilen biri erkek biri dişi olmak üzere zina eden iki bekârdır. Çünkü şayet zina eden kadınların kastedildiği bir önceki âyette olduğu gibi bu âyette de zina eden erkeklerin hükmü kastedilmiş olsaydı, bir

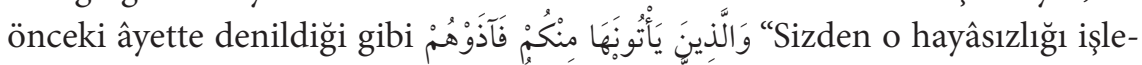

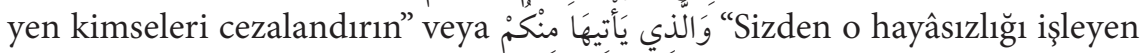
kimseyi cezalandırın" denilmesi gerekirdi. Nitekim önceki âyette kadınlar

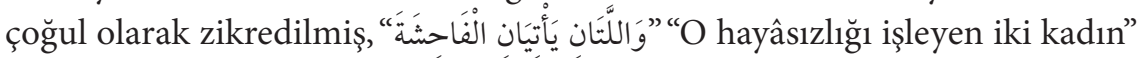
denilmemiştir. Zaten Araplar, bir kimseye ceza veya mükâfattan söz ettiklerinde, söz konusu şahısları çoğul veya o cinse işaret ettiği için tekil zikredip, "Şunu yapanlara şu ceza, şunu yapana şu ceza vardır" derler; "Şunu yapan

71 Hudayrî, Tefsîrü't-tâbiîn, I, 96, dipnot 1.

72 Taberî, Câmiu'l-beyân, V, 205.

73 Fahreddin er-Râzî, Mefâtîhu'l-gayb, VII, 37, 38; Reşîd Rızâ, Tefsîru'l-Menâr, III, 49; Öztürk, Kur'an'in Mu'tezilî Yorumu, s. 16o-62.

74 Taberî, biri الزجلان الفاعلان لا يكنى lafiğeri de الزانيان lablarıyla rivayetleri zikretmiş,

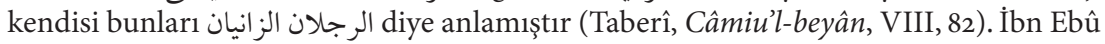
Hâtim’in lafzı da الرجلان الزانيان الزانيان şeklindedir (İbn Ebû Hâtim, Tefsîr, III, 895). 
iki kişiye şu ceza vardır" demezler. Ancak zina gibi biri erkek diğeri dişi iki farklı kişinin olduğu fiiller bunun istisnasını oluşturur. Dolayısıyla burada tesniyenin zikredilmiş olması (erkek ve kadın olmak üzere) fâil ve mef'ulün kastedildiğini gösterir. Şayet tesniye zikredilip de bununla her iki şahsın da bir fiilde münferit olarak bulunduğu veya bir fiilde müssterek bulunmadıkları bir durum kastediliyorsa, bu Arap dilinde bilinen bir husus değildir. Dolay1sıyla bu âyeti, iki erkeğe yoran görüşün fâsit olduğu açıktır. ${ }^{75}$

Burada şunu ifade etmek yerinde olacaktır: Aşağıda da üzerinde durulacağ 1 üzere, sonraki müfessirlerden bir kısmı, Mücâhid'in bu ifadelerinden hareketle, onun âyetten eşcinselleri anladığını ileri sürmüşlerdir. Ne var ki gerek Mücâhid'in ifadelerinin gerekse Taberînin onun görüşünü reddetmek üzere serdettiği uzun mülahazaların eşcinsellerle alakalı olduğu çok açık değildir. Sanki Mücâhid, "zina eden iki erkek" derken, karşı cinsle zina fiili işlemiş iki ayrı erkeği kastetmiş, Taberî de reddiyesini daha çok bunun üzerine kurmuş gibidir. Ama Mücâhid her neyi kastetmiş olursa olsun Taberî onun görüşünü, Arap dilinin mantığ çerçevesinde kabule değer bulmayıp reddetmektedir.

Mưtezilî Ebû Müslim el-İsfahânî, Nisâ sûresinin 15. âyetinde geçen, "kadınlarınızdan o hayâsızlı̆̆ 1 getirenlere" ifadesindeki kadınlarla, sevicilerin (es-sehhâkât), sonraki âyette geçen "içinizden o hayâsızlığı işleyen iki kişiyi" ifadesindeki iki erkekle de eşcinsellerin (ehlü'l-livât) kastedildiğini ileri sürmüştür. İsfahânînin bu görüşünü nakleden Fahreddin er-Râzî onun ileri sürdügü delillere ve onun bu delillerine karşı ileri sürülmüş delillere de ayrı ayrı yer vermiştir. ${ }^{76}$ Râzî, burada Selef'ten hiç kimseden böyle bir görüş nakledilmediği dolayısıyla İsfahânînin ileri sürdüğü görüşün icmâa aykırı olduğu iddiasına, "Bu memnu bir icmâdır; zira bu görüşü Mücâhid dile getirmiştir ki o da ileri gelen müfessirlerdendir. Ayrıca usûl-i fikıhta beyan edildiği üzere, âyet hakkında yeni bir tevil ortaya koymak (istinbat) mütekaddimînin görüşüne göre caizdir" şeklinde cevap vermiştir. ${ }^{77}$

Konunun bütünü göz önüne alındığında İsfahânînin, âyette sözü edilenlerin eşcinseller olduğunu ileri sürdüğü ve fakat görüşünü Mücâhid’den gelen rivayete dayandırmadığı anlaşılır. İmam Mâtürîdî de ikinci âyetin muhtemel anlamlarından birinin, Lût kavminin yaptığı gibi erkeğin erkeğe yaklaşması konusunda, özellikle erkekler için, 1. âyetin ise hem erkek hem de kadınlar için olabileceğini, bu durumda âyetin livataya had cezasını

75 Taberî, Câmiu'l-beyân, VIII, 83.

76 Fahreddin er-Râzî, Mefâtîhu’l-gayb, IX, 529.

77 Fahreddin er-Râzî, Mefâtîhu'l-gayb, IX, 529. 
zorunlu görmeyip tâzir cezasının uygulanacağını söyleyen Ebû Hanîfe'nin (ö. 150/767) görüşüne delil olacağını söylemiştir. ${ }^{78}$ Ancak Mâtürîdî de bu görüşünü Mücâhid’e nispet etmemiştir. Sonraki dönemlerde Hâkim el-Cüşemî (ö. 494/1101) (Ebû Müslim’e nispetle) ve Zemahşerî (herhangi birine nispet etmeksizin kile lafziyla), söz konu iki âyetten sevicilerin ve eşcinsellerin de anlaşıldığına zayıf bir görüş olarak değinmişlerse de Mücâhid'in adını onlar da zikretmemişlerdir. ${ }^{79}$ Dolayısıyla Râzî, İsfahânînin görüşünü temellendirmek ve desteklemek amaciyla, muhtemelen ilk defa Mücâhid'den gelen rivayeti bu doğrultuda anlamıştır.

İbn Kesîr, 16. âyetle ilgili rivayetler arasında Mücâhid'in görüşüne de yer vermiş, ${ }^{80}$ sonra da "Sanki o livatayı kastediyor, Allahü a lem" demiştir. İbn Kesîr bu görüşüyle Mücâhid’in maksadının çok açık olmadığını söylemiş, muhtemelen Râzînin anlayışından hareketle ve fakat bir ihtiyat payı da bırakarak onun görüşünü nakletmiştir. ${ }^{81}$ Süyûtî ise (ö. 911/1505) her iki âyetle ilgili görüşleri değerlendirmiş, hakkında hadis vârit olması ve lafzın çoğul gelmesi dolayısıyla 1. âyette zinanın, 2. âyette ise siganın tesniye gelmesi dolayısıyla livatanın kastedilmiş olduğu görüşünü benimsemiştir. Süyûtî, İbn Ebû Hâtim ve diğerlerinin nakline göre Mücâhid'in de âyeti böyle tefsir ettiğini ifade etmiştir. ${ }^{82}$ Öyle görünüyor ki önceki müfessirlerin Mücâhid'in sözlerini livata ile yorumlamaları Süyûtîyi de etkilemiştir.

Esasen İbn Atıyye ve İbnü'l-Arabî̀nin (ö. 543/1148) bu iki âyetle ilgili nakilleri göz önüne alındığında Mücâhid'in kastının ne olduğu daha iyi anlaşılacaktır. İbn Atıyye şöyle demektedir:

Mücâhid ve diğerleri, 1. âyet evli olsun olmasın kadınların geneliyle ilgilidir, 2. âyet de erkeklerle ilgilidir demiş, tesniye lafzıyla evli olan ve olmayan iki erkek sınıfını birbirinden ayırmıştır. Şu durumda erkeklerin cezası ezadır. Bu lafzın gerektirdiği bir görüştür. Metin zina eden sinıflar1 tam olarak kapsamıştır. Lafız yönünden 1. âyetteki "kadınlarınızdan" 2. âyetteki "sizden" ifadeleri de bunu teyit etmektedir. ${ }^{83}$

78 Mâtürîdî, Te’vîlât, III, 67 .

79 Hâkim el-Cüşemî, et-Tehzîb, II, 1491, 1492.

80 İbn Kesîr, Mücâhid’in görüşünü Taberînin rivayet lafızlarına yakın olan نزلت في الرجلين

81 İ̈bn Kesîr, Tefsîr, II, 235.

82 Süyûtî, el-İklîl, s. 84 .

83 İbn Atıyye, el-Muharrerü'l-vecîz, II, 22; krş. Kurtubî, el-Câmi', V, 86-87. 
İbnül-Arabî ise "Âyet bekâr ve evli erkeklerin geneliyle ilgilidir. Bu Mücâhid'in görüşüdür. $O, 1$. âyetteki zamirin müennes olduğunu, bunun kadınları; 2. âyetteki zamirin müzekker olduğunu bunun da erkekleri ifade ettiğini söyleyerek delil getirmiştir" demektedir. Dolayısıyla İbn Atıyye ve İbnü'l-Arabîye göre Mücâhid, "zina eden iki erkek" ile eşcinselleri değil, evli ve bekâr iki sınıf erkeği kastetmiş olmaktadır. Böylelikle Taberînin eleştirisini daha çok bu nokta üzerinden yürüttüğü anlaşılmaktadır. Nitekim İbn Atıyye, 1. âyette evli kadınlar -zımnen evli erkekler de bunun içine girer-, 2. âyette de bekâr erkeklerin ve kızların kastedildiğini söyleyen Süddî (ö. 127/745) ve Katâde gibi âlimlerin görüşünü de zikretmiş, Taberînin bu görüşü tercih ettiğini belirtmiştir. Ayrıca her iki âyetin Nûr sûresindeki âyetle neshedildiğinde icmâ olduğunu ifade etmiştir. İbnü’l-Arabî ise Taberînin 2. âyetin hem erkeğe hem de kadına uygun olduğu düşüncesiyle Mücâhid'i reddettiğini, -İbn Atıyye’nin dile getirdiği ilk âyetin zımnında erkeklerin de bulunduğu görüşünü reddederek- doğru olanın Mücâhid'in görüşü olduğunu söylemiştir. ${ }^{84}$

Kanaatimizce Mücâhid'den âyetle ilgili gelen diğer görüşlere bakıldığında, onun da pek çok müfessirin sözünü ettiği icmâın dışında olmadığı anlaşlır. Nitekim Mücâhid’e nispet edilen tefsirde Taberînin ondan rivayet ettiği görüşün yer almadığını; İbn Ebû Necîh'in nakline göre onun da bu âyetin Nûr sûresindeki âyetle neshedildiği kanaatinde olduğu görülür. ${ }^{85}$ Dolayısıyla Mücâhid âyetten eşcinselleri anlamış olsaydı, Kur'an'da başka yerde konuyla ilgili bir hüküm bulunmadığı için onun da İsfahânî gibi âyetin mensuh olduğunu söylememesi gerekirdi.

\section{Mâide: Hz. Îsâya Sofra İndirilmiş midir?}

Mücâhid'in farklı görüşlerinden biri de Mâide sûresine isim olan Hz. Îsânın sofra mucizesiyle ilgili âyetlere getirdiği yorumdur. Bilindiği gibi havariler, Hz. Îsẩdan Allah Teâlầnın kendilerine bir sofra indirmesini istemişler, Hz. Îsâ da onların bu isteklerini Allah Teâlâyya iletmiştir. Allah Teâlâ bunun üzerine şöyle buyurmuştur: "Onu size mutlaka indireceğim; fakat bundan sonra içinizden kim inkâr ederse, varlıklar âleminde hiç kimseye etmediğim azabı ona edeceğim." 86

84 İbnü'l-Arabî, Ahkâmü'l-Kur'ân, I, 465. Şu durumda İbnül-Arabînin Mücâhid’le, âyette eşcinsellerin kastedildiği görüşünü paylaştığı iddiası geçerliliğini yitirir (Öztürk, Kur'an'in Mu'tezilî Yorumu, s. 174).

85 Mücâhid, Tefsîr, s. 270; Kurtubî, el-Câmi', V, 86.

86 el-Mâide 5/112-115. 
Mücâhid “Üzerimize gökten bir sofra indir!" ifadesini, "Verilmiş bir misaldir; onlara herhangi bir şey indirilmemiştir" diye tefsir eder. ${ }^{87}$ Taberî onun bu cümlelerini, "Bu sadece şanı yüce Allah’n kullarına verdiği bir misaldir, bununla onlara Allah'in peygamberinden mucizeler istemelerini yasaklamıştır” şeklinde anlar. Taberînnin yine Mücâhid'den naklettiği şu ifadeler Mücâhid'in meramını daha iyi açıklar: "(Havarilerin istediği sofra) üstünde yiyecekler olan bir sofradır. İnkâr ettikleri takdirde azaba uğrayacakları söz konusu olunca sofradan vazgeçmişler, böylelikle onlara sofra indirilmemiştir." Taberî benzer bir görüşü Hasan-1 Basrîden de (ö. 110/728) nakletmiştir. ${ }^{88}$

Taberî, Mücâhid'in görüşünden önce, sofranın indirildiğine ve üstünde yer alan yiyeceklere dair pek çok rivayet nakletmiş, sonra da iki görüşten, Hz. Îsânın onların istekleri üzerine rabbinden istediği sofrayı Allah Teâlẩnın indirdiği görüşünün kendi kanaatine göre daha doğru olduğunu söylemiştir. Bu tercihinin sebebi de Allah resulü, sahabe ve müfessirlerden sofranın indirildiğine dair pek çok rivayetin gelmiş olmasıdır. Ayrıca âyette geçen, "Onu indireceğim" ifadesi de buna işaret etmektedir. Allah Teâlẩnın böyle söyleyip de sonra vaadinden dönmesi caiz değildir. ${ }^{89}$

Zemahşerî sofranın indiği yönündeki rivayetleri uzunca naklettikten sonra, isim vermeksizin Mücâhid'den gelen rivayeti nakletmiş ardından da Hasan-1 Basrînin, "Vallahi inmemiştir, şayet inseydi, 'Bizden sonrakiler için de bayram olsun' sözü gereği kıyamete kadar bayram olması gerekirdi” sözünü zikretmiş, doğru olanın sofranın indiği görüşü olduğunu da eklemiştir. ${ }^{90}$ Râzî, Mücâhid ve Hasan-1 Basrînin iki delile dayalı olarak sofranın indirilmediğini ileri sürdüklerini söylemiştir. Birinci delilleri, azabı duymaları üzerine af dileyip isteklerinden vazgeçmeleri, diğeri de Hz. Îsẩnın sofranın kendileri ve sonrakiler için bir bayram olmasını istemesidir. Onlara göre sofra şayet indirilmiş olsaydı, bu bayramın kıyamete kadar kalmış olması gerekirdi. Râzî, cumhurun Allah Teâlânın, “Onu indireceğim” diye kesin bir vaatte bulunması sebebiyle sofrayı indirdiği görüşünü benimsediklerini dile getirmiştir. O, Mücâhid ve Hasan-1 Basrînin delillerine de cevap vermiştir:

Birinci delilin cevabı şöyledir: Allah Teâlânın, "Sizden her kim ondan sonra inkâr ederse ona azap edeceğim” sözü şart ve cevaptır, bu sözün "Onu mutlaka indireceğim" sözüne taalluku yoktur. İkinci delilin cevabı

87 Taberî, Câmiu’l-beyân, XI, 230; İbn Ebû Hâtim, Tefsîr, IV, 1248.

88 Taberî, Câmiu'l-beyân, XI, 230, 231.

89 Taberî, Câmiu'l-beyân, XI, 231, 232.

90 Zemahşerî, el-Keşşâf, I, 694. 
ise şöyledir: Sofranın indiği gün onlar ve onların dini üzere bulunan sonraki kişiler için de bayram olmuştur. ${ }^{91}$

Beyzâvî (ö. 685/1286) indirilmediği görüşünü naklettikten sonra Mücâhid'den, "Bu, mucizeler isteyenlere Allah Teâlầnın verdiği bir misaldir” görüşünün nakledildiğini ilave etmiştir. ${ }^{92}$ İbn Kesîr'e göre Mücâhid ve Hasan-1 Basrîden gelen rivayetler sahih olup onların görüşünü, sofranın hıristiyanlar tarafından bilinmemesi ve kitaplarında da yer almaması güçlendirmektedir. Şayet indirilmiş olsaydı, pek çok sebepten nakledilmiş olması, kitaplarında tevâtüren veya en azından âhâd bir haber olarak bulunması gerekirdi. Bununla birlikte İbn Kesîr de cumhurun görüşünün doğru olduğu kanaatindedir. ${ }^{93}$

M. Reşîd Rızâ, İbn Kesîr’in görüşünü naklettikten sonra Râzînin görüşünü ve onun Mücâhid ve Hasan-1 Basrîye verdiği cevapları kaydetmekte, İbn Kesîr’in görüşleri çerçevesinde onun verdiği her iki cevabı da tenkit etmektedir. Ne var ki kendisi de bu bayramın Mâide isminden farklı bir bayram olmasının mümkün olduğunu, nitekim Hz. Îsânın Fısıh bayramında pek çok insanı az bir ekmek ve balıkla doyurmasının bunu tasdik ettiğini söylemektedir. Reşîd Rızâ, İnciller'den getirdiği uzun nakillerle, bu olayın yahudilerin ve hıristiyanların günümüze kadar ortak kutladıkları Fısıh bayramında olduğunu, hıristiyanların da halen bu günü kutsal akşam yemeği diye adlandırıp kutladıklarını, Mesih'in adıyla ekmek yiyip şarap içtiklerini belirtmektedir. Ona göre bu onların bir tahrifi olup Allah Teâlâ söz konusu mucizenin aslını onlara açıklamaktadır. ${ }^{94}$

Netice itibariyle Mücâhid, sofranın indirilmediğini, bunun bir misal olduğunu dile getirmiştir. Taberî ve Beyzâvînin de ifade ettikleri gibi, Mücâhid, "misâlün duribe" sözüyle, Allah Teâlânın Hz. Peygamber döneminde mucize bekleyenlere Hz. Îsânın hayatından bir misal vermiş, havarilerin de bir mucize istediklerini, ancak Allah Teâlầnın tehdidi karşısında bundan vazgeçtiklerini örnek vererek aslında mucize beklentisine girmeyi yasaklamıştır. Ne var ki Mücâhid'in bu görüşü cumhur tarafından kabule değer görülmemiştir. ${ }^{95}$

91 Fahreddin er-Râzî, Mefâtîhu'l-gayb, XII, 464.

92 Beyzâvî, Envârü't-tenzîl, II, 150; Elmalılı, Hak Dini, III, 367.

93 İbn Kesîr, Tefsîr, III, 231.

94 Reşîd Rizâ, Tefsîrül-Menâr, VII, 214-18.

95 Muhammed Esed, âyeti "Allah şüphe yok ki” dedi, "Ben onu size (her zaman) gönderirim” şeklinde çevirmiş, "innî münezzilühâ" ibaresinin süreklilik ifade ettiğini, böylelikle Allah’n maddi-manevi rızık vericiliğinin vurgulandığını, ayrıca Allahıın varlığının delili olarak bir mucize gösterilmesi talebinin kınandığına işaret ettiğini söylemiştir (Esed, Kur'an Mesajı, s. 220). Anlaşıldığı kadarıyla Esed, Mücâhid'in görüşünü beyan 


\section{Makām-1 Mahmûd: Hz. Peygamber'in Makamı Arşın Üzerinde midir?}

İsrâ sûresinin 79. âyetinde geçen "Rabbin seni övülmüş bir makama yükseltir" ifadesini, Mücâhid'in, "Onu kendisiyle birlikte arşının üzerine oturtur" şeklinde tefsir ettiğine dair bir rivayet nakledilmiştir. ${ }^{96}$ Ondan gelen bu rivayet çok ciddi tartışmalara sebep olmuştur. Taberî, âyetin tefsiriyle ilgili doğru olanın, Ebû Hüreyre’nin (ö. 58/678) Hz. Peygamber'den naklettiği, “O şefaattir” veya "O, ümmetime şefaat edeceğim makamdır" görüşü olduğunu söylemiş, diğer bazı sahabî ve tâbiînden getirdiği rivayetlerle de makām-1 mahmûdun şefaat makamı olduğunu teyit etmiştir. Bununla birlikte o, Mücâhid’e nispet edilen görüşü destekler tarzda bazı rivayetleri de zikredip şu değerlendirmede bulunmuştur: "Söz konusu âyetin tefsiriyle ilgili, sahih olan Allah resulü, sahabe ve tâbiînden gelen rivayetler olsa da Mücâhid'in, Allah Teâlầnın Muhammed’i arşının üzerine oturtacağı yönündeki sözü, ne haber ne de dirayet (nazar) yönünden reddedilemeyecek bir görüştür."97

Taberî rivayet yönünden, ne Allah resulünden ne bir sahabîden ne de tâbiînden bunun imkânsız olduğuna dair bir rivayet gelmediğini ileri sürer. Dirayet yönünden ise İslamı benimseyenlerin bunun anlamı konusunda üç ayrı görüş benimsediklerini söyleyip ayrıntılı bir şekilde sıraladığı aklî delillerle bunun mümkün olduğunu ispat yoluna gider. Taberî daha sonra, İslam’ı benimseyenlerden hiç kimsenin Mücâhid'in Allah’ın Hz. Muhammed'i arşın üzerine oturtacağına dair görüşünü imkânsız görmediğini belirtir. Kendisi de bu görüşü teyit edici mahiyette ifadeler sarfeder. ${ }^{98}$

Birtakım rivayetlerde Taberînin aslında bu görüşte olmadığı, Bağdat Hanbelîleri'nin üzerinde uyguladıkları baskılar sebebiyle bu görüşe meylettiği anlatılmaktadır. Mesela Yâkūt el-Hamevînin (ö. 626/1229) rivayetine göre, Hanbelîler Taberîye Ahmed $b$. Hanbel'in fikhî görüşlerini ve (Hz. Peygamber'in) arşa oturması konusunu sorarlar. Taberî, Ahmed

eden Taberînin ifadelerinden ilhamla bu yargıya ulaşmakta, âyette doğrudan vâki olmuş bir mucizenin anlatıldığı görüşüne mesafeli bir tutum takınmakta, böylelikle de Mücâhid'in görüşüne yaklaşmaktadır.

96 Taberî, Câmiu’l-beyân, XVII, 529.

97 Taberî, Câmiu'l-beyân, XVII, 529-31.

98 Taberînnin görüşünün ayrıntıları için bk. Taberî, Câmiu'l-beyân, XVII, 531-33. İleride yer verileceği gibi, Vâhidî, Mücâhid’den gelen rivayeti sert bir şekilde reddeder. Ayrıca eserin nâşiri, Taberînin ileri sürdüğü Hz. Peygamber'den bir haberin olmaması delilinin, aksini değil, Mücâhid'den gelen görüşün bâtıl olduğunu gösterdiğini, çünkü bu haberin gaybî ve itikadî bir bilgi taşıdığını ve bu konuların da ancak sahih bir haberle bilinebileceğini, bu meselenin ispatında da dirayetin fayda sağlamayacağını dile getirir (Vâhidî, et-Tefsîrüll-basît, XIII, 445, neşredenin notu). 
b. Hanbel'in kayda değer bir fikhî ihtilafının olmadığını, arşa oturmanın da imkânsız olduğunu söyleyip şu şiiri inşat eder: "Allah bir yâreni olmasından münezzehtir / Onun arşında bir oturan da yoktur." Bunun üzerine Hanbelîler Taberîye sözlü ve fiilî saldırıda bulunurlar ve Taberînnin kapısına Hz. Peygamber'in, Allah nezdinde bir makamı olduğunu, Leys b. Ebû Süleym'in de (ö. 143/760-761) Mücâhid'den böyle naklettiğini yazarlar. Rivayetin devamında Taberînin onlardan özür dileyen bir kitap yazdığı, bu konudaki görüşünü zikredip farklı görüşte olanları tenkit ettiği ve bunları Hanbelîler'e okuduğu anlatıllı. ${ }^{99}$

Esasen Taberînin "istiva, vech, yed" gibi haberî sıfatlara yaklaşımında, zaman zaman Arap dilinin ifade unsurlarını dikkate almak ve bu çerçevede âyetleri tefsir etmekle birlikte, önemli ölçüde Selef'in ya da ehl-i hadisin anlayışını benimsediği ve bunları mümkün mertebe tevil cihetine gitmediği ve genelde âyetleri zâhiri üzere anlamayı tercih ettiği bilinen bir husustur. ${ }^{100}$ Dolayısıyla onun Hz. Peygamber'den ve Mücâhid'den gelen rivayetleri göz önüne alıp Kur'an’’n zâhirine ve Selef'in anlayışına da aykırı görmeyerek bu görüşü mümkün gördüğünü düşünmek gerekir. Buna göre Taberînin önceden Mücâhid'den gelen görüşü reddettiği, üzerinde kurulan baskılar sebebiyle bu görüşünden vazgeçip söz konusu rivayeti mümkün gördügünü düşünmek, onun bu tür konulardaki görüşünü göz ard1 etmek olacaktır. Ancak burada şunu da ilave etmek gerekecektir: Taberî Mücâhid'den gelen görüşü sırf tâbiîn ulemasından/Selef'ten olduğu için değil, kendi paradigmasına uygun düştügü için kabul etmiştir. Yoksa o, yukarıdaki örneklerde de görüldügü ve daha farklı örneklerde de görüleceği üzere, Kur'an’ın zâhirine ve icmâa uymayan hususlarda onun görüşünü de reddetmekten çekinmemiştir. Burada ise ilginç bir şekilde icmâa aykırı bu görüşü kabul etmiştir.

İbn Abdülber (ö. 463/1071) konuyla ilgili şunları söyler:

Mücâhid, her ne kadar Kur'an tevilini bilen ileri gelenlerden biri olsa da onun âlimler nezdinde kabul görmeyen iki görüşü vardır: Onlardan biri 'Yüzler vardır, o gün ışıl ışıldır; rablerine bakmaktadırlar'101 âyetine

99 Yâkūt, Mu'cemüll-üdebâ', VI, 245o. Goldziher, bu tasavvuru Markos İncili’ndeki (16/19) anlatımla ilişkilendirmenin yanı sıra 317 (929) yılında Bağdat’ta, bu görüşü benimseyen (Ebû) İshak el-Mervezînin (ö. 340/951) başını çektiği birtakım olayların olduğunu da kaydeder (Goldziher, Mezâhib, s. 122-24).

100 Yâkūt, Mu'cemüll-üdebâ', VI, 2462; Goldziher, Mezâhib, s. 111-16, 117; Öztürk, “Taberînin Tefsir Anlayışında Selefîlik", s. 17-51.

101 el-Kiyâme 75/22, 23. 
getirdiği, 'sevabı beklerler' görüşü; diğeri de 'Umulur ki rabbin seni makām-1 mahmûda eriştirir' âyeti hakkındaki görüşüdür." ${ }^{\text {"102 }}$

İbn Abdülber, sonra da Mücâhid'den kendisine ulaşan bilgiyi nakleder. Bu görüşün sahabe ve sonrakilerin icmâına aykırı olduğunu, bu âyetin tevilinde ulemanın makām-ı mahmûdu şefaat olarak anladığını, dirayet yönünden meselenin uzunca tartışılabileceğini ama yerinin burası olmadığını belirtir. ${ }^{103}$ Dolayısıyla İbn Abdülber, Mücâhid'in görüşünü reddetmiş, herhangi bir tevil cihetine gitmemiştir.

İbn Atıyye, konuyla ilgili şunları söyler:

Taberî, Mücahid'in de aralarında bulunduğu bir fırkanın, 'Makām-1 mahmûd, Allah Teâlânın Muhammed'i arşta yanına oturtmasıdır' dediğini nakletmiş ve [yine bu fırkanın] bir hadis rivayet ettiğini söylemiş̧tir. Taberî aşırı bir görüşe meylederek bunun imkânını desteklemiş̧ir. Oysa böyle bir görüş ancak anlam konusunda aşırı serbest olmak kaydıyla çıkarılabilir ki bu da makul olmayan bir tavırdır. Bununla birlikte bu görüşün rivayet edilmesinde sakınca görülmez. Nihayetinde ilim/ilim adamları onu uygun şekilde tevil eder. ${ }^{104}$

İbn Atıyye, Nakkāş'tan da (ö. 351/962) şunu nakleder: "Ebû Dâvûd esSicistânî (ö. 275/889) demiştir ki, 'Bu hadisi inkâr eden bize göre itham edilir', ilim ehli bu konuyu hala tartışmaktadır.” İbn Atıyye kendi görüşünü de, "Tevili üzere caiz olduğunu inkâr eden kimse (itham edilir)"105 diye belirterek bu rivayetin tevil edilmesi ve fakat inkâr edilmemesi gerektiği kanaatine varır.

İbn Atıyye'den Taberînnin âyeti tefsiriyle ilgili görüşüne ve İbn Abdülberr'in Mücâhid hakkındaki değerlendirmelerine yer veren Kurtubî (ö. 671/1273), Mücâhid'in görüşünü naklettikten sonra, bunun imkânsız bir tevil olmadığını ileri sürerek Taberînnin cümleleriyle meseleyi izah etmiştir. O, Mücâhid'in sözünde geçen "kendisiyle beraber" (maahû) ifadesini de diğer bazı âyetlerde geçtiği şekliyle tevil etmiş, sonra da bütün bunların bir mekâna değil, yüksek

102 İbn Abdülber, et-Temhîd, VII, 158; Kurtubî, el-Câmic, X, 311. Ömer Nasuhi Bilmen, Mücâhid'e ait iki görüşün reddedildiğini, birincisinin makām-1 mahmûdu şefâat-i kübrâya hamletmesi, ikincisinin de Kıyâme sûresinin 23. âyetiyle ilgili görüşü olduğunu söyler. Bilmen'in şefâat-i kübrâdan kastı, Mücâhid'in makām-1 mahmûdu mezkûr şekilde anlaması olmalıdır (Bilmen, Büyük Tefsir Tarihi, I, 272).

103 İbn Abdülber, et-Temhîd, VII, 158.

104 İbn Atıye, el-Muharrerü'l-vecìz, III, 479.

105 İbn Atıye, el-Muharrerü'l-vecîz, III, 479. 
derecelere işaret ettiğini söylemiştir. Dolayısıyla Kurtubî de bu görüşün tevil edilerek kabul edileceği fikrini benimsemiştir. ${ }^{106}$

Vâhidî (ö.468/1076), müfessirlerin âyette sözü dilen makām-1 mahmûdun, şefaat makamı olduğunda icmâ ettiklerini söylemiş; ${ }^{107}$ ayrıca Mücâhid’in görüşünü, "Fâsit bir tefsir, rezil bir görüş", "maahû" sözünü de "korkunç" (mûhış) ve "çok çirkin" (fezı') diye nitelendirmiş ve kitabın (Kur'an) metninin bu sözün fâsit olduğunu ilan ettiğini söylemiştir. Delillerini dil bilimsel açıdan getiren Vâhidîye göre, "be-a-se", "oturtmak", "makam” da "mak'ad" anlamına gelmez. Aksine bu lafızlar, şefaat hadisinde zikredilen anlamlara işaret eder. ${ }^{108}$

Râzî, Vâhidînin âyetin tefsirinde icmâ olduğu görüşüne yer verip bu görüşü makām-1 mahmûd ibarelerinin de desteklediğini ifade eder. Ayrıca Vâhidînnin bu görüşü reddeden keskin sözlerini aynıyla alır, onun delillerinin yanı sıra bu görüşün tecsimi gerektirdiğini ifade ederek kendi delillerini serdeder, "Böylelikle sabit oldu ki bu görüş, ancak aklı kıt, dini zayıf kimselerin eğilim gösterebileceği rezil, değersiz bir sözdür” diyerek noktayı koyar. ${ }^{109}$

Zehebî, "Peygamberimizin arşı üzerine oturacağı meselesinde, sabit bir nas yoktur, hatta bu konuda gelen hadis de zayıftır (vâh), Mücâhid'in âyeti bu yönde tefsirini kelamcılardan bir kısmı reddetmiştir” demiş, bu görüşü benimseyen ve (Ebû İshak) el-Mervezî (ö. 340/951) gibi aşırı giden bir k1sım âlimlerin görüşlerine yer verdikten sonra, bu anlayışı doğru bulmadı̆̆ nı hissettiren ifadeler kullanmıştır. ${ }^{110}$ Mücâhid'in biyografisinde ise "Âyetin tefsiriyle ilgili Mücâhid'den gelen görüşü reddedenler olmuştur" demiştir. ${ }^{111}$

Esasen Mücâhid'in makām-ı mahmûdu şefaat makamı olarak tefsir ettiği bir görüş daha gelmiş, bu görüşüyle o da icmâa dahil olmuştur. Nitekim İbn Ebû Necîh tarikiyle gelen Mücâhid tefsirinde sadece şefaat makamı görüşüne yer verilmiş; Taberî de biri yine İbn Ebû Necîh’ten olmak üzere iki ayrı tarikten bunu rivayet etmiştir. ${ }^{112}$ Kanaatimizce Mücâhid'in hem o görüşte hem bu görüşte olması mümkün değildir. Zira bu görüşlerden birinin diğerine zıt olduğu açıktır. Kaldı ki Mücâhid yukarıdaki bazı örneklerde görüldüğü üzere, kimi âyetleri tevil etmiş, bu bakımdan âyetleri tefsirde tevil yöntemine

106 Kurtubî, el-Câmi‘, X, 311, 312.

107 Vâhidî, el-Vasît, III, 122.

108 Vâhidî, et-Tefsîrü'l-basît, XIII, 444-47.

109 Fahreddin er-Râzî, Mefâtîhu'l-gayb, XXI, 387-88.

110 Zehebî, el-Ulüv, s. 124, 170, 171.

111 Zehebî, Mîzânüll-i'tidâl, III, 439.

112 Mücâhid, Tefsîr, s. 441; Taberî, Câmiu’l-beyân, XVII, 527. 
ilk başvuranlardan biri olmuştur. Kiyâme sûresindeki âyetlere getirdiği, "Onlar rablerinin sevabını beklerler"113 şeklindeki yorum ve bu yorumun zaman içerisinde farklı mezhepler tarafından rü'yetullahın mümkün olmadığ 1 görüşüne kadar uzanan yorumlara uç verdiği düşünüldüğünde, Râzî gibi müteahhir âlimlerin de dile getirdiği üzere tecsim ve teşbihe kapı aralayan bu yorumun Mücâhid tarafından dile getirilmiş olması mümkün gözükmemektedir. Zaten Zehebî de Mücâhid'den bu görüşü nakleden Leys b. Ebû Süleym’in zayıf ve muhtelit bir râvi olduğuna dair görüşler nakletmiştir. ${ }^{114}$

\section{Rü’yetullah: İnsanlar Rablerini Görecekler mi?}

Mücâhid'in en tartışmalı ve akılcı bir müfessir olarak nitelendirilmesine sebep olan en belirgin görüşü, Kıyâme sûresinin, "Yüzler vardır o gün ış1 1şıldır; rablerine bakmaktadırlar"115 âyetlerini tefsiridir. Taberînin rivayetine göre Mücâhid âyette geçen نَّاظرَّة ifadesini, تنتظر منه الثواب "O’nun sevabını beklerler" diye anlamıştır. Taberî, bu görüşü bir başka tarikten, "Yarattıklarından hiç kimse onu göremez" ilavesiyle rivayet etmiştir. Mansûr'dan (ö. 132/750) gelen bu görüşleri, A'meş’ten gelen, "O’nun rızkını ve lütfunu beklerler" rivayeti de desteklemektedir. Taberî ayrıca Mansûr'un, "İnsanlar 'Onlar böylece rablerini göreceklerdir' hadisini konuşuyorlardı. Mücâhid’e insanlar ' $\mathrm{O}$ görülür' diyorlar, dedim. 'O görür, fakat hiçbir şey onu göremez' dedi” rivayetini nakletmiştir. ${ }^{116}$ Taberî, Mücâhid’in bu görüşünden önce İkrime (ö. 105/723), Hasan-1 Basrî ve Atıyye el-Avfîden (ö. 111/729-730), “Onların rablerine gerçek anlamda bakacakları” görüşünü zikretmiş, iki görüşten tercihe değer olanın, İkrime ve Hasan-1 Basrî̀den gelen görüş olduğunu söylemiş, buna delil olarak da İbn Ömer'in Hz. Peygamber'den naklettiği ve söz konusu âyetlerin tefsiri niteliğindeki bir hadisi getirmiştir. ${ }^{117}$

Mücâhid bu görüşüyle, ilk defa Cehmiyye gibi fırkaların dile getirdiği, özellikle Mưtezile tarafından hararetle savunulacak ve Ehl-i sünnet ile Mútezile arasındaki kırılma noktalarından birini teşkil edecek olan rü’yetullah meselesinin öncüsü olmaktadır. ${ }^{118}$

113 el-Kiyâme 75/22, 23.

114 Zehebî, Mîzânüll-ítidâl, III, 420-21. A. Muhammed Şâkir, "Hıfzında problem olmakla birlikte, hadisi bizim nezdimizde sahihtir" der (bk. Taberî, Câmiu'l-beyân, II, 325, neşredenin notu; konuyla ilgili Nâsırüddin el-Elbânînin kanaatleri için bk. Hudayrî, Tefsîrüt-tâbiìn, I, 109, 110).

115 el-Kiyâme 75/22, 23.

116 Taberî, Câmiu'l-beyân, XXIV, 72, 73.

117 Taberî, Câmiu'l-beyân, XXIV, 73.

118 Ahmed b. Hanbel, er-Red, s. 129-30; Mâtürîdî, Tẻvîlât, V, 4-34; İbn Hazm, el-Fasl, III, 2. 
Mücâhid'in görüşünün izdüşümlerinden biri erken dönemde Ahfeş elEvsat’ta (ö. 215/830) görülür. Ahfeş isim vermemiş olsa da söz konusu âyeti şöyle tefsir etmiştir: "Âyet diyor ki, Allahu a'lem: 'Allah'a bakmak, ondan gelecek nimetlere ve rızıklara bakmaktır.' Nitekim şöyle dersin: 'Sadece Allah’a ve sana bakıyorum.' Bu, 'Allah'tan ve senden gelecek ihsanlara bakıyorum' anlamına gelir."119 Ebû Ali el-Cübbâî (ö. 303/916) ve Ebû Müslim el-İsfahânî gibi Mu'tezilîler ise âyetteki إلىلى 'nin harf-i cer değil, الآلاء "nimetler" kelimesinin müfredi olduğunu iddia ederek, âyete "Rablerinden gelecek nimeti beklerler" anlamını vermek istemişlerdir. ${ }^{120}$

Mâtürîdî söz konusu âyeti, hakiki anlamda bakmaya hamletmiş ve rü’yetullahın delillerinden biri olarak görmüş, Mücâhid'in adını zikretmeksizin, tevil ehlinden bir kısmının söylediği gibi, bu âyetin rablerinden gelen sevabı bekleyeceklerine hamledilebileceğini; ancak bunu Allah’n görülemeyeceği anlamında değil, henüz nail olmadıkları başkaca sevaplar beklemeleri şeklinde anlaşllabileceğini söylemiştir. ${ }^{121}$

Kādî Abdülcebbâr (ö. 415/1025), Allah Teâlầnın görülemeyeceğinin delilleri arasında söz konusu âyeti de görür. Müfessirlerden nakledildiğine göre âyetin akıl ve kitap deliline uygun olması için tevili, Allah'ın sevabını ve nimetlerini beklemektir. ${ }^{122}$ Kādî Abdülcebbâr doğrudan Mücâhid'in adını zikretmemiş olsa bile kendinden önceki müfessirlere referansla âyeti, Mücâhid'den nakledildiği gibi tevil etmiştir.

İbn Abdülber, Mücâhid’den gelen rivayeti şöyle değerlendirmiştir:

Mücâhid'in bu görüşü, Hz. Peygamber'den gelen sahih sünnet, sahabe ve Selef'in cumhurunun görüşleriyle reddedilir. Bu, Ehl-i sünnet nezdinde kabul görmemiş bir görüştür. Onlara göre bu konuda muteber olan Hz. Peygamber'den sabit olan görüştür. Allah resulü dışında herhangi bir âlimin görüşü alınabilir de reddedilebilir de. Mücâhid her ne kadar Kur'an tefsirini bilme konusunda öncü birisiyse de bu konudaki görüşü âlimler nezdinde makbul görülmemiştir. ${ }^{123}$

İbn Hazm (ö. 456/1064), Mu'tezile ve Cehm b. Safvân’ın (ö. 128/745-746) Allah’n görülemeyeceği görüşünde olduklarını dile getirdikten sonra, "Bize

119 Ahfeş el-Evsat, Meâni'l-Kurân, II, 557, 558.

120 İbn Hazm, el-Fasl, III, 3; Hâkim el-Cüşemî, et-Tehzîb, X, 7188.

121 Mâtürîdî, Te’vîlât, X, 349.

122 Kādî Abdülcebbâr, el-Usûulül-hamse, s. 74.

123 İbn Abdülber, et-Temhîd, VII, 157. 
Mücâhid'in de bu görüşte olduğu bilgisi ulaştı, bu konuda o mâzurdur, çünkü haber ona ulaşmamıştır" demektedir. ${ }^{124}$

Vâhidî, Mücâhid’in görüşünü naklettikten sonra, dilde bir otorite olduğunu belirttiği Ezherîden (ö. 905/1499), "nâzıra”nın "intizar"dan geldiğini söyleyen kimsenin hata ettiğini, çünkü Araplar’nn نظرت "Bir şeye baktım” sözünü "Onu bekledim” anlamında kullanmadıklarını, نظرت فلاء "Falana baktım" dediklerinde, "Onu bekledim" anlamında kullandıklarını, birincisi kullanıldığında sadece "gözle görmek", نظرتُ في أمر كذا denildiğinde ise "kalple tefekkür etmek" anlamında olduğu bilgisini vermektedir. Vâhidî, "nazar"ın Kur'an'da "intizar" anlamında kullanıldığı yerleri de şahit getirmekte, hiçbirinde harf-i cerrin olmadığını, "vech" (yüz) ifadesinin de "nazar" ve "ilâ" ile kullanıldığında "rü’yet”"ten başka bir anlama gelmediğini ilave etmektedir. Dolayısıyla ona göre, "nazar" "vech"e nispet edildiğinde ne tefekkür ne de beklemek anlamına gelmektedir. Bu âyette söz konusu iki anlam olmadığına göre rü’yeti kabul etmeyenlerin bunun üzerine söyleyecekleri bir söz kalmamıştır. Sahih senedlerle gelen sünnet de âyetteki nazarı rü'yet olarak tefsir edenleri desteklemektedir. ${ }^{125}$

Hâkim el-Cüşemî, âyetteki "nazar"a "gözün görmesi" ve "beklemek" anlamlarının verildiğini, beklemek anlamının da iki şekilde yorumlandığını, birincisinin "Rablerinin sevabını beklerler" anlamında, Mücâhid, Hasan-1 Basrî, Saîd b. Cübeyr, Ebû Sâlih (es-Semmân) (ö. 101/719-720) ve Dahhâk’tan geldiğini, Hz. Ali'den de böyle bir görüş nakledildiğini, ikincisinin de "Kerametlerinin yenilenmesini umarlar" anlamında olduğunu söylemiştir. O ayrıca Vâhidînin de dile getirdiği, na-za-ra fiilinin harf-i cerle kullanıldığında sadece "gözle görmek" anlamına geldiği görüşünün de yanlış olduğunu dile getirmiştir. ${ }^{126}$

Zemahşerî ise âyetin tefsirinde, harf-i cerrin öne alınmasının hasr ifade ettiğini, buna göre onların sadece Allah'a bakıp (ondan nimet beklediklerini), başkasına bakmadıklarını söylemiş, "nazar"ın harf-i cerle kullanılmasının "beklemek ve ümit etmek" anlamında olduğunu çeşitli örneklerle izah etmiştir. Buna göre anlam, "Onlar nimet ve şerefi ancak rablerinden umarlar" şeklinde olmuştur. Zemahşerî âyeti bu şekilde izah etmekle birlikte Mücâhid’e herhangi bir referansta bulunmamıştır. ${ }^{127}$

124 İbn Hazm, el-Fasl, III, 2.

125 Vâhidî, et-Tefsîrüll-basit, XXII, 510.

126 Hâkim el-Cüşemî, et-Tehzîb, X, 7188.

127 Zemahşerî, el-Keşşâff, IV, 622. 
Râzî ilgili âyetin tefsirinde, Ehl-i sünnet'in cumhurunun bu âyeti Allah’in kıyamette görüleceğinin ispatında delil kabul ettiklerini, Mu'tezile’nin ise burada biri âyetin zâhirinin rüyetullaha delalet etmediği, diğeri de âyetin tevil edilmesi gerektiğine dair iki yaklaşımı olduğunu dile getirmektedir. $\mathrm{O}$, önce Mu'tezile'nin iddialarına yer vermekte, sonra da bunları Ehl-i sünnet' in genel kabulleri çerçevesinde reddetmekte ve fakat burada doğrudan Mücâhid'in adını zikretmemektedir. ${ }^{128}$

Buraya kadar nakledilen görüşlerden, isim verilsin veya verilmesin Mücâhid'in âyeti, "Rablerinin sevabını/nimetini beklerler" șeklindeki tefsirine kaynaklık ettiği ve âyetin bu minvalde anlaşılmasında belirleyici olduğu anlaşılmaktadır. Her ne kadar Cüşemînin de yer verdiği diğer bazı tâbiîn âlimleri gibi Mücâhid'in de âyeti söz konusu şekilde anladığı ve fakat bununla rü’yetullahın imkânsız oluşunu kastetmediği düşünülebilirse de diğer rivayetlerde gelen, "Yarattıklarından hiç kimse onu göremez" şeklindeki farklı yorumu, onun rü’yetullahın imkânsız olduğu görüşünün de öncü ismi olduğunu göstermektedir. Nitekim İbn Ebû Necîh, Mücâhid'in, genelde Ehl-i sünnet âlimlerinin rü'yetullahın delili olarak gördükleri ve "Allah’a bakmak" olarak yorumladıkları, ${ }^{129}$ "Güzel ameller işleyenlere en güzel mükâfat ve fazlası vardır"130 âyetindeki "ziyade"ye "bağışlama ve rıza” anlamı verdiğini nakletmiștir. ${ }^{131}$ Böylelikle iki görüş arasında bir uygunluk ortaya çıkmıştır. Lâlekâî (ö. 418/1027), Leys'ten, Mücâhid'in bahse konu "ziyade"ye "rabbe bakmak" anlamını verdiği rivayetini nakletmişse de ${ }^{132}$ yukarıda yer verildiği gibi Leys'in zayıf olması, bu görüşün Mücâhid’e aidiyetini zayıflatmaktadır.

\section{Mizan: Ameller Tartılacak mı?}

Rivayete göre Mücâhid, "Mizan o gün haktır; kimin tartıları ağır gelirse..."133 âyetindeki "mizan"1, "hüküm" (kaza), "hakk"1 "adalet", "tartılar" (mevâzîn) kelimesini de "iyilikler" (hasenât) diye tefsir etmiş, böylelikle âyetin anlamının, "O gün adaletle hüküm verilecektir...” şeklinde olduğunu söylemiştir. ${ }^{134}$ Mücâhid,

128 Fahreddin er-Râzî, Mefâtîhu'l-gayb, XXX, 730-733.

129 Taberî, Câmiu'l-beyân, XV, 62-69.

130 Yûnus 10/26.

131 Mücâhid, Tefsîr, I, 380; Taberî, Câmiu'l-beyân, XV, 70.

132 Lâlekâî, Şerh, III, 512. İbn Kesîr’ in “ziyade”yi "Allah’a bakmak” olarak anlayanlar arasında Mücâhid'i de sayması bu rivayet sebebiyle olmalıdır (İbn Kesîr, Tefsîr, IV, 262; Hudayrî, Tefsîrü't-tâbiîn, I, 113).

133 el-A'râf $7 / 8$.

134 Taberî, Câmiu'l-beyân, XII, 309-311. 
"Kiyamet günü adalet terazilerini kurarız"135 âyetini de İbn Ebû Necîh’ten gelen rivayete göre, "Bu bir meseldir", Leys'ten gelen rivayete göre ise "adalet" diye tefsir etmiş, bu görüşüyle iki âyetin anlamının aynı olduğunu ifade etmek istemiştir. O, bu yorumuyla tutarlı olacak şekilde, âyetin devamındaki "Hardal tanesi ağırlığınca bir şey varsa, onu getiririz" mealindeki ifadeyi ise yine İbn Ebû Necîh'ten gelen rivayete göre "eteynâ" (getiririz) şeklinde okuyanlardan farklı olarak, "âteynâ" (veririz) şeklinde okumuş ve "Karşıllğını veririz" diye tefsir etmiştir. ${ }^{136}$

Mücâhid bu görüşüyle de hakiki anlamda bir mizanın varlığını kabul eden diğer rivayetlere muhalefet etmiş, âyeti "mesel" ifadesiyle aklî/mecazi bir yöntemle tefsir etmiş olmaktadır. Taberî, Amr b. Dînâr’n (ö. 126/744), "İki kefesi olan bir mizan olduğunu düşünüyoruz"137 şeklindeki görüşünü tercih etmekte, âyetlerde kastedilenin gerçek anlamda iyilik ve kötülüklerin tartılacağı bir mizan olduğunu, hadislerin de bunu desteklediğini söylemekte, meseleyi uzunca ele alarak âyetlerin tevil edilemeyeceğini çeşitli delillerle ortaya koymaktadır. ${ }^{138}$ Kādî Abdülcebbâr da mizanla ilgili âyetleri kimi müfessirlerin yaptığ gibi adalet anlamında mecaza hamletmek mümkünse de bu tür âyetleri mümkün mertebe mecaza hamletmemek gerektiğini, âyetlerdeki "ağırlık" ve "hafiflik" gibi tabirlerin, mizanı bilenen tartı anlamında anlamayı gerekli kıldığını dile getirmektedir. Bununla birlikte, iyilik ve kötülüklerin araz olduğu, bunların tartılmasının mümkün olmadığ 1 itirazından hareketle, birinin nur, diğerinin de zulmet k1lınarak tartılabileceğini söylemekte ve böylelikle başka bir tevile gitmektedir. ${ }^{139}$ Cüşemî ve Zemahşerî ise her iki görüşü de zikredip herhangi bir tercihte bulunmamaktadırlar. ${ }^{140}$ Râzî naklettiği görüşler çerçevesinde, lafzı zâhirî anlamda almaya bir engel bulunmadığını, bir dili ve iki kefesi olan bir terazinin varlığını ispatın muhal olmadığını ifade etmektedir. ${ }^{141}$ Netice itibariyle Ehl-i sünnet hakiki anlamda amellerin tartıldığı bir mizanı kabul ederken, Mu'tezile'den bir kısmı, amellerin araz oldukları, arazların da kendi kendilerine var olmadıkları için tartılmalarının mümkün olmadığı gerekçesiyle mizanı âdil bir hüküm verme ile tevil etme yoluna gitmektedir. ${ }^{142}$

135 el-Enbiyâ 21/127.

136 Taberî, Câmiu'l-beyân, XVII, 311.

137 Taberî, Câmiu'l-beyân, XVIII, 451.

138 Taberî, Câmiu'l-beyân, XII, 311-14.

139 Kādî Abdülcebbâr, Şerhu'l-Usûli'l-hamse, s. 735; Toprak, “Mîzan”, s. 211-12.

140 Hâkim el-Cüşemî, et-Tehzîb, II, 2502; Zemahşerî, el-Keşşâf, II, 89.

141 Fahreddin er-Râzî, Mefâtîhu'l-gayb, XIV, 203.

142 İbn Hacer, Fethu'l-bârî, XIII, 537-39; Teftâzânî, Şerhu'l-akāid, s. 100-101; Mestçizâde, el-Mesâlik, s. 101. Bizim de Mücâhid'in bu görüşünden kendisi vesilesiyle haberdar 
Mücâhid'den bunlardan başka da aklî tevil örnekleri gelmiştir. Mesela "Ve elbiseni temizle"143 âyetini Mücâhid, "Amelini temizle ve onu sslah et" şeklinde anlamıştır. Esasen İbn Abbas ve diğer tâbiîn âlimlerinden de aynı âyetle ilgili "Elbiseni günahtan temizle" anlamıyla Araplar’ın "günahtan uzak durma” yı kastettiklerine dair görüşler gelmiş; dolayısıyla Mücâhid, diğerlerinden sadece lafzî bir farklılıkla ayrılmıştır. ${ }^{144}$ Yine "yıldız kaydığı zaman"145 âyetini Mücâhid'in, "Kur'an indiği zaman" şeklinde anladığına dair A'meş’ten bir rivayet gelmiştir. Mücâhid’in aynı zamanda âyete, "Süreyyâ yıldızı battığı zaman” anlamını verdiği de nakledilmiş, Taberî onun bu görüşünü tercih etmiştir. $^{146}$

\section{Sonuç}

Mücâhid b. Cebr'in, kāri, fakih ve sika bir âlim olduğunda rical âlimlerinin ittifakı vardır. Tâbiîn âlimleri içinde daha çok tefsir ilmiyle ön plana çıan Mücâhid'i Şâfiî̀, Ahmed b. Hanbel, Buhârî ve Taberî gibi âlimler tefsirde mutlak bir otorite kabul etmişlerdir. Mücâhid Kur'an'da anlatılan bazı kıssaların geçtiği yerleri görmek, ilim talebi için çokça seyahat etmek, Ehl-i kitap’tan bilgi sormak gibi tahkik ve araştırma yolları yanında tefsirde reye önem vermesiyle temayüz etmiştir. Bizzat kendisinden reyin faziletine dair görüşler nakledilmesi, onun bahse konu özelliğinin en önemli göstergelerindendir. İbn Abbas'tan naklettiği ve tek râvisi olduğu, "ilimde derinleşenlerin müteşabihlerin tevilini bilecekleri”ne dair görüş, Mücâhid'in tefsire bakışının bir yansıması gibidir. Bununla birlikte Mücâhid'den rivayet edilen tevil örnekleri sadece müteşâbih âyetlerle sınırlı değildir; onun tevil ettiği âyetler daha geniş bir daireyi ihata etmektedir. Buna göre Mücâhid'in, bazı rivayetlerde geldiği üzere İbn Abbas'la başlayan tevil faaliyetinin çerçevesini genişlettiği, böylelikle tefsirin erken döneminde tevilin kayda değer ilk örneklerini verdiği söylenebilir.

olduğumuz M. Reşîd Rızânın meseleyi ayrıntılı şekilde tartışması için bk. Reşîd Rızâ, Tefsîrül-Menâr, VIII, 285-289.

143 el-Müddessir 74/4.

144 Taberî, Câmiu'l-beyân, XXIII, 9-12; Ebû Nuaym, Hilye, III, 281.

145 en-Necm 53/1.

146 Taberî, Câmiu'l-beyân, XXII, 495-497; Goldziher, “Sa'd b. Muâz’ın ölümü sebebiyle arş titremiştir" şeklindeki rivayette geçen "arş"ı Mücâhid'in "Sa'd’ın kabre taşındığg tabuttur, sıcaktan dolayı tahtaların genişlemesinden dolayı sallanmıştır” şeklinde tevil ettiğini ifade eder (Goldziher, Mezâhib, s. 127-29). Ancak kaynaklar, bu tevilin Mücâhid'e değil, İbn Ömer'e ait olduğunu, Mücâhid'in sadece râvi konumunda bulunduğunu kaydederler (bk. Hudayrî, Tefsîrüt-tâbiîn, I, 96-97). Mücâhid’e nispet edilen diğer bazı mecazi yorumlar için bk. Kesler, "Mücâhid b. Cebr", s. 442-43. 
İsrâiloğulları’ndan cumartesi yasağını çiğneyen halka verilen maymuna dönüştürülme cezasının maddi değil, manevi olduğu; Hz. Îsâya sofranın indirilmediği; kıyamet günü müminlerin Allah’ görmelerinden değil, onun nimetlerini bekleyecek olmalarından söz edildiği; kıyamet gününde insanların amellerinin tartılacağı düşünülen mizanın, gerçek anlamda bir mizan değil, iyilik ve kötülüklerin karşılıklarının adalet ve hakkaniyetle verileceği gibi konulardaki görüşleri, Mücâhid' in tevil örneklerini oluşturur. Bu yorumları onun klasik dönemde, "tefsirde ihtiyatla yaklaşılması gereken bazı görüşleri olduğu" kanaatini oluştururken, çağdaş dönemde kimi araştırmacılarca "aklî tefsir yönelişinin erken bir müjdecisi” olarak görülmesine sebep olmuştur.

Öte yandan tevile dayalı yorumlarına tamamıla aykırı, Allah Teâlânın Hz. Peygamber'i kendisiyle birlikte arşının yanı başına oturtacağı şeklinde tecsim ve teşbihe varan bir görüş de Mücâhid’e nispet edilebilmiştir. Onun genel tavrına uygun düşmeyen böyle bir görüş ya ona sehven isnat edilmiş ya da itikadî mezhep tartışmalarının alevlendiği bir dönemde otoriter kişiliği kullanılarak onun üzerinden meşrulaştırılmak istenmiştir. Pek çok tarikten gelmesi sebebiyle Mücâhid’e aidiyetinde neredeyse şüphe bulunmayan rü’yetullah meselesindeki yaklaşımına aykırı, "Allah’ın görüleceği” rivayetinin de onun bu farklı yaklaşımını bertaraf edip onu Selef'in genel çizgisine çekmek veya rüyetullahı imkânsız gören fırka mensuplarına firsat vermemek gayesiyle ona isnat edildiği hatıra gelmektedir. Bunların yanı sıra Nisâ sûresinin 16. âyetinde görüldügü üzere, Mücâhid'in ibarelerine farklı anlamlar da yüklenebilmiş, bazı şâz görüşlere onun üzerinden meşruiyet kazandırılmak istenmiştir.

Tefsir merviyyatının geneline bakıldığında, Mücâhid'in zihin dünyasında henüz sistemli bir tevil anlayışının olmadığı görülür. Zira o aynı minvalde yorumlanabilecek bazı âyetlerin tefsirinde tevil yoluna giderken diğer bazılarında gitmemiştir. Genellikle "Bu Allah Teâlẩnın verdiği bir meseldir” tarzında, birden çok yerde kullandığı ifadeyle bazı âyetleri tevil etmiş, bu tür yerlerde de aklî tefsirlerin örneklerini vermiştir. Bu yönüyle Mücâhid, kimi âyetleri tefsirin erken bir döneminde tevil ederek rey ile tefsir yöntemine başvuranların öncü isimlerinden biri olmuştur. Âlimler onun bu tür görüşlerine çoğu zaman muhalif bir tutum takınmış; özellikle tefsirinde Kur'an’ın zâhirine ve icmâa ciddi anlamda önem veren Taberî, Mücâhid’e kimi zaman sert eleştiriler yöneltmiştir. Bununla birlikte Mücâhid, bu görüşlerinden bir kısmıyla sonraki itikadî mezheplere ve Kur'an'a akılcı yaklaşımların hız kazandığı çă̆daş dönem Kur'an yorumcularına ilham kaynağı olmuştur. 


\section{Bibliyografya}

Ahfeş el-Evsat, Meâni'l-Kur'ân, nşr. Hüdâ Mahmûd Kurâa, Kahire: Mektebetü'l-Hancî, $1411 / 1991$.

Ahmed b. Hanbel, Kitâbü’s-Sünne, nşr. Muhammed b. Saîd b. Sâlim el-Kahtânî, I-II, Demmâm: Dâru İbni'l-Kayyim, 1406/1986.

Ahmed b. Hanbel, er-Red ale'l-Cehmiyye ve'z-Zenâdıka, nşr. Sabrî b. Selâme Şâhin, Riyad: Dârü’s-sebât, 1424/2003.

Beyzâvî, Envârüt-tenzîl ve esrârü't-te’vîl, nşr. M. Abdurrahman el-Mar'aşlî, I-V, Beyrut: Dâru ihyâi't-türâsi'l-Arabî, t.y.

Bilmen, Ömer Nasuhi, Büyük Tefsir Tarihi, I-II, İstanbul: Bilmen Yayınevi, 1973-74.

Buhârî, Muhammed b. İsmâil, el-Câmiu’s-sahîh, nşr. M. Züheyr b. Nasr, I-VIII, Beyrut: Dâru tavkín-necât, 1422/2001.

Buhârî, Muhammed b. İsmâil, et-Târîhu'l-kebîr, I-VIII, Haydarâbâd: Dâiretül-maârifi'lOsmâniyye, t.y.

Câhiz, Kitâbü'l-Hayevân, nşr. M. Bâsil Uyûnü’s-Sûd, I-VII, Beyrut: Dârü'l-kütübi'l-ilmiyye, $1424 / 2003$.

Coşkun, Ahmet, “Mesh”, DİA: Türkiye Diyanet Vakfı İslâm Ansiklopedisi, 2004, XXIX, 303304.

Ebû Nuaym el-İsfahânî, Hilyetü'l-evliyâ', I-X, Kahire: Matbaatü’s-saâde, 1394-99/1974-79.

Ebû Zeyd, Nasr Hâmid, el-İtticâhü'l-aklî fi't-tefsîr, Beyrut: el-Merkezü's-sekāfiyyü'l-Arabî, 2007.

Elmalılı Muhammed Hamdi, Hak Dini Kur'an Dili, nşr. İsmail Karaçam v.dğr., I-X, İstanbul: Azim Dağıtım, t.y.

Esed, Muhammed, Kur'an Mesajı: Meal-Tefsir, trc. Cahit Koytak - Ahmet Ertürk, İstanbul: İşaret Yayınları, 1999.

Fahreddin er-Râzî, Mefâtîhu'l-gayb: et-Tefsîrül-kebîr, I-XXXII, Beyrut: Dâru ihyâi'ttürâsi'l-Arabî, 1420.

Goldziher, I., Mezâhibü't-tefsîri'l-İslâmî, trc. Abdülhalîm Neccâr, Kahire: Mektebetü'lHancî, 1374/1955.

Hâkim el-Cüşemî, et-Tehzîb fìt-tefsîr, nşr. Abdurrahman b. Süleyman es-Sâlimî, I-X, Kahire - Beyrut: Dârü’l-kitâbi'l-Misrî - Dârül-kitâbi'l-Lübnânî, 1440/2019.

Hudayrî, Muhammed b. Abdullah, Tefsîrüt-tâbiîn: Arz ve dirâse mukārene, I-II, Riyad: Dârü'l-vatan, t.y.

Işıcık, Yusuf, Kur'an’ı Anlamada Temel Bir Problem: Te’vil, İstanbul: Hikmetevi Yayınları, 2019.

İbn Abdülber en-Nemerî, et-Temhîd limâ fil-Muvatta' mine'l-meânî ve'l-esânîd, nşr. Mustafa b. Ahmed el-Alevî - M. Abdülkebîr el-Bekrî, I-XXIV, Mağrib: Vizâretü’l-umûmi'levkāf, $1387 / 1967$. 
İbn Âşûr, M. Tâhir, et-Tahrîr ve't-tenvîr, I-XXX, Tunus: ed-Dârüt-Tûnusiyye, 1984.

İbn Atıyye el-Endelüsî, el-Muharrerü̉l-vecîz fî̀ tefsîrill-kitâbi'l-azîz, nşr. Abdüsselâm Abdüşşâfî̀ Muhammed, I-X, Beyrut: Dârü’l-kütübi'l-ilmiyye, 1422/2001.

İbn Ebû Hâtim, el-Cerh ve't-ta dîll, I-IX, Haydarâbâd: Dâiretü'l-maârifi'l-Osmâniyye, 137173/1952-53.

İbn Ebû Hâtim, Tefsîrül-Kurâni'l-azîm, nşr. Es'ad Muhammed et-Tayyib, I-X, Mekke: Mektebetü Nizâr Mustafa el-Bâz, 1419.

İbn Hacer el-Askalânî, Fethu'l-bârî, nşr. Abdülazîz b. Abdullah b. Bâz v.dğr. I-XIII, Beyrut: Dârü'l-ma'rife, 1379.

İbn Hacer el-Askalânî, Tehzîbü̉t-Tehzîb, I-XII, Haydarâbâd: Matbaatü Dâireti'l-maârifỉnNizâmiyye, 1325-27/1907-1909.

İbn Hazm, el-Fasl, I-V, Kahire: Mektebetü'l-Hancî, t.y.

İbn Hibbân, es-Sikāt, I-IX, Haydarâbâd: Dâiretü'l-maârifi'l-Osmâniyye, 1393-99/1973-79.

İbn Kesîr, Ebü'l-Fidâ, Tefsîrül-Kurâni'l-azîm, nşr. Sâmî b. Muhammed es-Selâme, I-VIII, Riyad: Dâru Taybe, 1420/1999.

İbn Kuteybe, Tèvîlü muhtelifil-hadîs, nşr. M. Muhyiddin el-Esfar, Beyrut - Devha: elMektebetü'l-İslâmî - Müessesetü'l-işrâk, 1419/1999.

İbn Sa'd, et-Tabakātüll-kübrâ, nşr. M. Abdülkādir Atâ, I-VIII, Beyrut: Dârü’l-kütübi'lilmiyye, 1410/1990.

İbn Teymiyye, Takıyyüddin, Mukaddime fî usûli't-tefsîr, Beyrut: Dâru mektebeti'l-hayât, 1400.

İbnü'l-Arabî, Ebû Bekir, Ahkâmü'l-Kurân, nşr. M. Abdülkādir Atâ, I-IV, Beyrut: Dârü'lkütübi'l-ilmiyye, 1424/2003.

Kādî Abdülcebbâr, Şerhu'l-Usûli'l-hamse, nşr. Abdülkerîm Osman, Kahire: Mektebetü Vehbe, $1408 / 1988$.

Kādî Abdülcebbâr, el-Usûlüll-hamse, nşr. Faysal Büdeyr Avn, Küveyt: Matbûâtü Câmiati'lKüveyt, 1998.

Kesler, Muhammed Fatih, “Mücâhid b. Cebr”, DİA, 2006, XXXI, 442-443.

Kurtubî, Muhammed b. Ahmed, el-Câmi` li-ahkâmi'l-Kurân, nşr. Ahmed el-Berdûnî İbrâhim Ettafeyyiş, I-X, Kahire: Dârü'l-kütübi'l-Mısriyye, 1384.

Lâlekâî, Şerhu usûli itikādi Ehlis'sünne ve’l-cemâa, nşr. Ahmed Sa'd b. Hamdân el-Gāmidî, I-IV, Riyad: Dâru Taybe, 1423/2003.

Mâtürîdî, Te’vîlât, nşr. Mecdî Baslûm, I-X, Beyrut: Dârü’l-kütübi'l-ilmiyye, 1426/2005.

Mavil, Kılıç Aslan, Mâtürîdî Kelâmında Te’vil, Ankara: İSAM Yayınları, 2017.

Mestçizâde Abdullah Efendi, el-Mesâlik fi'l-hilâfiyyât beyne'l-mütekellimîn ve'l-hukemâ', nşr. Seyit Bahcıvan, Beyrut: Dâru Sâdır, 1428/2007.

Mücâhid b. Cebr, Tefsîrüll-imâm Mücâhid b. Cebr, nşr. M. Abdüsselâm Ebü’n-Nîl, Kahire: Dârü'l-fikri'l-İslâmiyyi'l-hadîse, 1410/1989. 
Öztürk, Mustafa, Kur'an’ın Mu'tezilî Yorumu, Ankara: Ankara Okulu Yayınları, 2018.

Öztürk, Mustafa, “Taberînin Tefsir Anlayışında Selefîlik ve Ilımlı Zâhirîlik”, Bir Müfessir Olarak Muhammed b. Cerîr et-Taberî Sempozyumu, Konya: Ünlem Ofset, 2010, s. 17-52.

Reşîd Rızâ, Tefsîrü'l-Menâr, I-XII, Kahire: el-Hey'etü'l-Mısriyyetü'l-âmme li'l-kitâb, 1990.

Safedî, Yûsuf b. Hilâl, Keşfüll-esrâr ve hetkü'l-estâr, nşr. Bahattin Dartma, I-V, İstanbul: Türkiye Diyanet Vakfı Yayınları - İrşad Kitabevi, 1440/2019.

Sezgin, Fuat, Târîhu't-türâsi'l-Arabî, trc. Mahmûd Fehmî Hicâzî v.dğr., I-VIII, Riyad: Câmiatü’l-İmâm Muhammed b. Suûd el-İslâmiyye, 1411/1991.

Süyûtî, el-İklîl fî istinbâtitt-tenzîl, nşr. Seyfeddin Abdülkādir el-Kâtib, Beyrut: Dârü’lkütübi'l-ilmiyye, 1401/1981.

Süyûtî, el-ìtkān fî ulûmi'l-Kur'ân, nşr. M. Ebü’l-Fazl İbrâhim, Kahire: el-Hey'etü’lMisriyyetü'l-âmme li'l-kitâb, 1394/1974.

Taberî, Muhammed b. Cerîr, Câmiu'l-beyân an te’vîli âyill-Kurân, nşr. Ahmed M. Şâkir, I-XXIV, Beyrut: Müessesetü'r-risâle, 1420/2000.

Teftâzânî, Şerhu'l-akāid, nşr. Ali Kemal, Beyrut: Dâru ihyâi't-türâsi'l-Arabî, 1437.

Toprak, Süleyman, “Mîzan”, DİA, 2005, XXX, 211-212.

Vâhidî, et-Tefsîrü'l-basît, nşr. Muhammed b. Sâlih b. Abdullah el-Fevzân v.dğr., I-XXV, Riyad: Câmiatü'l-İmâm Muhammed b. Suûd el-İslâmiyye, 1430.

Vâhidî, el-Vasît fî tefsîri'l-Kur'âni'l-mecîd, nşr. Âdil Ahmed Abdülmevcûd v.dğr., I-IV, Beyrut: Dârü'l-kütübi'l-ilmiyye, 1415/1994.

Yâkūt el-Hamevî, Mu'cemüll-üdebâ', nşr. İhsan Abbas, I-VII, Beyrut: Dârü'l-garbi'l-İslâmî, $1414 / 1993$.

Zehebî, Mîzânü̉l-ittidâl, nşr. Ali Muhammed el-Bicâvî, I-IV, Beyrut: Dârü'l-ma'rife, 1382/1963.

Zehebî, Siyeru a'lâmin-nübelâ’, I-XVIII, Kahire: Dârü'l-hadîs, 1427/2006.

Zehebî, el-Ulüv lìl-aliyyi'l-gaffâr fî îzâhi sahîhi'l-ahbâr ve sekimihâ, nşr. Ebû Muhammed Eşref b. Abdülmaksûd, Riyad: Mektebetü edvâi’s-selef, 1416/1995.

Zemahşerî, el-Keş̧̧âf, I-IV, Beyrut: Dârü'l-kitâbi'l-Arabî, 1407. 


\section{Ta'wīl in the Early Period of Tafsīr: Mujāhid b. Jabr's Rational Qur'an Exegesis}

Mujāhid b. Jabr (d. 103/721) is one of the prominent scholars of tābi ìn generation. There is consensus among scholars that he was a reciter (qāri'), a jurist (faqì $)$, and a trustworthy (thiqa) scholar. A disciple of Ibn 'Abbās (d. 68/687-688), he was particularly known among tābi ìn for his contributions to the science of Qur'an exegesis ( $\operatorname{tafsir}$ ), and therefore has been referred to by such appellations as al-Imām and the leader of reciters and exegetes (shaykh al-qurrä' wa-l-mufassirin). Eminent scholars, such as al-Shāfíì (d. 204/820), Aḥmad b. Ḥanbal (d. 241/855), al-Bukhārī (d. 256/870), and al-Ṭabarī (d. 310/923) valued his narratives and regarded him as an incontestable authority in tafsir.

Mujāhid comes to the fore for his emphasis on personal opinion ( $\left.r a^{\prime} y\right)$ in tafsìr, as well as research and verification methods, such as visiting the places where some of the stories in the Quran took place, traveling for the pursuit of knowledge, and asking for information from the People of the Book (Ahl al-kitäb). The fact that he himself conveyed his opinions about the virtue of the ray is one of the most important indicators of his aforementioned features. The tradition that those who deepen their knowledge will know the interpretation of the ambiguous verses (mutashābihāt), whose only narrator from Ibn 'Abbās is Mujāhid, may be seen as an expression of his conception of tafsir. Noteworthy in this context is that he interprets some verses through metaphor and allegory. This interpretation of his and others like it gave rise in the classical period to the opinion that he had "some views in tafsir that should be approached with caution," leading some contemporary scholars such as Goldziher (d. 1921) to regard him as an "early harbinger of the tendency to rational exegesis."

One of the most controversial examples of his rational exegesis concerns the conversion into monkeys of the Israelites who had violated the Saturday ban. While the majority of the exegetes understood from the verses that the people in question had been literally transformed into monkeys, Mujāhid claimed that this was not but an allegory and that there was no conversion to monkeys in the real sense, but, in the sense that they were transformed into monkey-like people in terms of their character traits. Most exegetes, especially al-Ṭabarī, rejected Mujāhid's view on the grounds that it was tantamount to not accepting the other punishments given to the Israelites, and the metaphorical interpretation in this way was contrary to the literal meaning of the verse as well as to consensus. Mujāhid's view has been mostly accepted in the modern approach to tafsir , where rational tendencies become more prevalent.

Regarding the table miracle of Jesus, Mujāhid said, "This is an allegory; nothing was sent down to them." This statement has been read to mean that the apostles abandoned their wishes when Allah informed them that He would bring down the table, but would inflict great torment on them if they did not believe. However, most exegetes, following the view of al-Hasan al-Bașrī (d. 110/728) —who thinks that "if this table had been brought down, that day should have been a holiday among Christians" - did not accept his view, holding instead that the table was offered and associating this miracle with some festivals celebrated by Christians. 
An opinion has been attributed to Mujāhid that he interpreted the expression "Your Lord will raise you to a praised position" in verse 79 of sūrat al-Isrä' as "He puts him on His Throne with Himself." The majority of exegetes understood the same verse as "the authority of intercession." While al-Ṭabarī and some literalists (Ahl al-hadìth) accepted this view of Mujāhid and tried to explain its possibility, hadith scholars, such as Ibn 'Abd al-Barr (d. 463/1071) and al-Dhahabī (d. 748/1348), as well as commentators, such as al-Wāhiidī (d. 468/1076) and al-Rāzī, strongly opposed it. In fact, the attribution of this view to Mujāhid seems problematic in terms of both transmission chain and theory. Regarding transmission, Lays b. Abi Sulaym (d. 143/760-61) is considered a weak narrator. In terms of theory, Mujāhid adopted, just like the majority of the scholars, the view that the verse refers to the authority of intercession, depending on stronger narrative chains. It is impossible for one who prefers rational interpretations in many occasions and agrees with other scholars that the verse signifies intercession to adopt, at the same time, a view that evokes anthropomorphism (tashbih and tajsim).

It is related that Mujāhid interpreted the passage "They look at their lords on that day" in verse 23 of sürat al-Qiyāma as signifying that "They expect his reward" and that he justified this interpretation of the verse with "Because no one can see him." His view was rejected based on the traditions from the Prophet as well as rational evidence. Mu'tazilites, on the other hand, resorted to Mujāhid's reading to argue against Ahl al-sunnah, who often made use of the verse in order to prove the possibility of seeing God (ru'yat Allah). This is the most famous case of Mujāhid's rational interpretation, for which he achieved fame as a rational mufassir.

Mujāhid interprets the sentence "The scale is real that day; as for those who have heavy scales..." in the $8^{\text {th }}$ verse of the al-A'râf in a figurative manner, claiming that the verse is a parable. According to Mujāhid's reading, this and similar verses indicate that good and bad deeds will be met in a fair and equitable manner, rather than suggesting the existence of a literal scale. While Ahl al-sunnah scholars accept the existence of a literal scale, some of the Mu'tazilites chose to interpret the scale as representing justice, in a manner similar to the interpretation of Mujāhid. Mujāhid did not yet have a fully conceptualized understanding of metaphor. $\mathrm{He}$ usually implied metaphorical meanings through his expression "this is a parable," which he used at times and gave examples of rational interpretation in such cases. In this respect, Mujāhid seems to open the door, in an early period of Islam, to a method called interpretation ( $t a^{\prime} w i \bar{l}$ ), a metaphor-based or rational exegesis. Although scholars have often approached his views with caution, through some of these views he inspired later theological sects and contemporary Qur'an commentators. These views, therefore, justify the thesis that he was an early representative of rational exegesis.

Keywords: Tafsìr, Mujāhid b. Jabr, ta'wīl, personal opinion (ra'y), rational Qur'an exegesis. 